\title{
Investigating the role of chemical and physical processes on organic aerosol modelling with CAMx in the Po Valley during a winter episode
}

\author{
A. Meroni ${ }^{1,2}$, G. Pirovano ${ }^{2}$, S. Gilardoni ${ }^{3}$, G. Lonati ${ }^{1}$, C. Colombi ${ }^{4}$, V. Gianelle ${ }^{4}$, M. Paglione ${ }^{3}$, V. Poluzzi ${ }^{5}$, G.M. Riva ${ }^{2}$, \\ A. Toppetti ${ }^{2}$ \\ ${ }^{1}$ Dipartimento di Ingegneria Civile e Ambientale, Politecnico Milano, Milano, 20133 \\ ${ }^{2}$ Ricerca sul Sistema Energetico (RSE), via Rubattino 54, Milano, 20134 \\ ${ }^{3}$ Consiglio Nazionale della Ricerca - ISAT, Bologna, 40129 \\ ${ }^{4}$ ARPA Lombardia, Settore Monitoraggi Ambientali, Milano, 20129 \\ ${ }^{5}$ ARPAE Emilia Romagna, CTR Aree Urbane, Bologna, 40122
}

\begin{abstract}
Traditional aerosol mechanisms underestimate the observed organic aerosol concentration, especially due to the lack of information on secondary organic aerosol (SOA) formation and processing. In this study we evaluate the chemical and transport model CAMx during a one-month in winter (February 2013) over a $5 \mathrm{~km}$ resolution domain, covering the whole Po valley (Northern Italy). This works aims at investigating the effects of chemical and physical atmospheric processing on modeling results and, in particular, to evaluate the CAMx sensitivity to organic aerosol (OA) modeling schemes: we will compare the recent 1.5D-VBS algorithm (CAMx-VBS) with the traditional Odum 2-product model (CAMx-SOAP). Additionally, the thorough diagnostic analysis of the reproduction of meteorology, precursors and aerosol components was intended to point put strength and weaknesses of the modeling system and address its improvement.

Firstly, we evaluate model performance for criteria PM concentration. $\mathrm{PM}_{10}$ concentration was underestimated both by CAMx-SOAP and even more by CAMx-VBS, with the latter showing a bias ranging between -4.7 and $-7.1 \mu \mathrm{g} \mathrm{m}^{-3}$. $\mathrm{PM}_{2.5}$ model performance was to some extent better than $\mathrm{PM}_{10}$, showing a mean bias ranging between $-0.5 \mu \mathrm{g} \mathrm{m}^{-3}$ at rural sites and $-5.5 \mu \mathrm{g} \mathrm{m}^{-3}$ at urban and suburban sites. CAMx performance for OA was clearly worse than for the other PM compounds (negative bias ranging between $40 \%$ and $-75 \%$ ). The comparisons of model results with OA sources (identified by PMF analysis) shows that the VBS scheme underestimates freshly emitted organic aerosol while SOAP overestimates. The VBS scheme correctly reproduces biomass burning (BBOA) contributions to primary OA concentrations (POA). In contrast VBS slightly underestimates the contribution from fossil-fuel combustion (HOA), indicating that POA emissions related to road transport are either underestimated or associated to higher volatility classes. The VBS scheme under-predictes the SOA too, but to a lesser extent than CAMx-SOAP. SOA underestimation can be related to corresponding underestimation of either aging processes or precursor emissions. This indicates that improvements in the emission inventories for semi- and intermediate-volatility organic compounds are needed for further progress in this area. Finally, the comparison between modeled and observed SOA sources points out the urgency to include processing of OA in particle water phase into SOA formation mechanisms, to reconcile model results and observations.
\end{abstract}

\section{Highlights}

- CAMx performance for OA are worse than for other PM components

- SOAP scheme shows a better performance than VBS, due to an error compensation

- VBS allows a better repartition of primary and secondary OA than SOAP scheme

- POA volatility distribution and SVOC and IVOC emissions need improvement

- Aqueous phase mechanism is necessary to reconcile OA observations and modeling

\section{Keywords}

Organic aerosol modelling, CAMx, AMS, Positive Matrix Factorization, Po Valley 


\section{Introduction}

Outdoor air pollution is one of the biggest environmental risks for human health, leading to about 3 millions premature deaths every year worldwide (WHO, 2016). In Europe atmospheric pollution is responsible for more than 400.000 premature deaths a year (EEA, 2016), with the largest share due to fine particulate matter $\left(\mathrm{PM}_{2.5}\right)$ exposure. Organic aerosol (OA) accounts for up to $50 \%$ of fine particles over Europe (Zhang et al., 2007; Putaud et al., 2010), and its budget, sources, and atmospheric processing are still characterized by large uncertainty (Hallquist et al., 2009; Heald et al., 2010). A better knowledge of OA, and thus of fine particulate matter, is mandatory to support effective air quality control and remediation measures.

OA is composed by thousands of different chemical species, characterized by different degree and type of functionalization, and thus different chemical and physical properties. The main sources of primary OA are wood burning, vehicular emissions, industrial activities, energy production, cooking, residential heating in winter and transport from the sea (Mohr et al., 2012; Crippa et al. 2013; Crippa et al., 2014; Fuzzi et al., 2015). Recent studies showed that more than half of OA is composed by oxidized organic aerosol (OOA), i.e. a proxy of secondary organic aerosol (SOA) (Zhang et al., 2007; Ng et al., 2010; Crippa et al., 2014). Up to recent years, most Chemistry Transport Models (CTMs) adopted simplified OA modules based on surrogate molecules, mostly derived from the "2-product model" of Odum et al. (1996) further developing the work of Pankow (1994). An example for the Odum approach is the Secondary Organic Aerosol Processor (SOAP, Strader et al., 1999) implemented as the default SOA chemistry module in the chemistry and transport model CAMx (Environ, 2015). SOAP assumes that each VOC precursor forms several surrogate compounds that can coexist in the gas and in the aerosol phase, according to their saturation concentration (Donahue et al., 2009). The two main limitations of such basic approaches are the assumptions of nonvolatility and non-reactivity of primary organic aerosol (POA). Experimental findings prove that some components of POA are semi-volatile and the vapor-phase portion can undergo photochemical oxidation (Robinson et al., 2007; Donahue et al., 2009). Additionally, volatility change associated with SOA chemical aging is not accounted for by traditional models (Jimenez et al., 2009; Koo et al., 2014). As a consequence, CTMs implementing standard SOA chemistry often over-predict fresh POA and underpredict SOA, especially in summer (Bergstrom et al., 2012).

The volatility basis set (VBS) approach Donahue et al. $(2006,2011)$ allows to take into account POA volatility and multiple generation SOA production. VBS can be used in two configurations. The 1-dimension approach (1D-VBS) describes OA evolution based on OA volatility (Donahue et al., 2006). The 2-dimension approach (2D-VBS) describes OA evolution in the 2-D space defined by effective saturation concentration $\mathrm{C}^{*}\left(\mu \mathrm{g} \mathrm{m}^{-3}\right)$ and the oxidation degree (Donahue et al., 2012). We use a hybrid VBS approach 1.5D-VBS (Koo et al., 2014), where OA evolution follows specific path in such space, reducing computational cost. The implementation of VBS approach in CTMs introduced a valuable improvement both in model performance as well as in the knowledge of the key processes influencing the modeled results. For example Zhang et al. (2013) showed that in a simulation with non-volatile POA and a simplified SOA formation mechanism POA are largely overestimated, while SOA are underestimated. The application of the VBS scheme indicated that also the volatility distribution of the aerosols is extremely important (Lane et al., 2008; Fountoukis et al., 2011). Namely, the distribution of OA emissions into the low volatility bins appears to be important for the predicted POA because it has great impact on the initial partitioning between the aerosol and the gas phase (Tsimpidi et al., 2010). Bergstrom et al. (2012) showed that VBS-based OA models can give reasonably good results, mainly for summer than for winter conditions, but more observational studies are needed to constrain the VBS parameterizations and to improve emission inventories for both anthropogenic and biogenic sources. Ciarelli et al. (2015) applied the SOAP and 1.5D-VBS with two different volatility sets in CAMx simulations over Europe. Two sensitivity tests with volatility distributions based on previous chamber and ambient measurements data were performed too. The total OA concentrations obtained with the volatility data from chamber measurements were on the average about $42 \%$ lower than the concentration estimated by SOAP. In contrast, using volatility data from ambient measurement increased OA concentrations by about $42 \%$ and brought model results and observations into a slightly better agreement. In our study, the CAMx model is applied with both the SOAP and the 1.5D-VBS scheme focusing on the Po Valley, a well-known European hot-spot for many air pollutants. In the Po Valley OA accounts for more than 
$40 \%$ of fine particulate mass $\left(\mathrm{PM}_{1}\right.$ and $\left.\mathrm{PM}_{2.5}\right)$ in winter, and SOA accounts for up to $50 \%$ of OA (Gilardoni et al., 2011; Larsen et al., 2012; Gilardoni et al., 2014; Gilardoni et al., 2016). Surrounded by the Alps to the North and North-West and by the Apennines to the South, the Po Valley experiences poor circulation of air masses. In addition, the occurrence of frequent and prolonged wind calm periods and atmospheric stability conditions during the night-time favor the accumulation of locally-emitted pollutants, especially during the coldest months. These distinctive features of the Po Valley make it an interesting challenge to model SOA. The Po Valley has been subject to several modeling studies pointing out the influence of both meteorological and chemical processes on model performance. Lonati et al. (2010) report that underestimation of $\mathrm{PM}_{2.5}$ mass by CAMx model essentially derives from a $60 \%$ underestimation of organic matter, whereas a rather good agreement is observed for the other chemical species and especially for the ammonium-nitrate system. In addition, Pernigotti et al (2013) concluded that CTM models continue to experience problems in reproducing the $\mathrm{PM}_{10}$ concentration levels observed in the Po Valley, particularly underestimating the winter concentration. One key factor partially explaining this $\mathrm{PM}_{10}$ underestimation is meteorology, particularly concerning wind speed overestimation. But other factors, such as the systematic cold bias in the ambient temperature and uncertainties in biomass burning emissions estimates, may also affect the results. Similar findings were reported by Pirovano et al. (2015).

Actually, literature works by Fountoukis et al. (2014) and Ciarelli et al. (2016) discuss VBS results in CTMs at European scale, the former presenting MPE for OA only, the latter also considering precursors and secondary aerosols, but both neglecting the influence of meteorology. Fountoukis et al. (2016) discuss PMCAMx for Paris area, but with a different version of VBS and still focusing on OA only; van der Gon et al. (2015) present VBS diagnostic evaluation, but focusing on the influence of emission estimates, whereas the VBS sensitivity analysis presented by Murphy et al (2012) is, once again, limited to the OA fraction.

On the basis of these previous results and taking advantage of a rather unique experimental data set available for Po Valley, we performed a thorough comparison of meteorology, precursors and all aerosol components in order to assess CAMx strengths and weaknesses and to acquire knowledge to address its improvement. in reproducing OA concentrations. Both the complementary techniques of model "diagnostic evaluation" (Dennis et al., 2010) have been applied: i) model performance evaluation (MPE) considered each physical and chemical process simulated, also investigating the influence that the accuracy in their reproduction can have on the other modeling steps (Godowitch et al, 2011; Zhang et al., 2006a) ; ii) sensitivity analysis (Shorshani et al., 2017; Zhang et al., 2006b) has been performed in order to evaluate the influence of the adopted chemical scheme (SOAP and 1.5D-VBS) on OA reconstruction, also relying on local OA mass spectra from positive matrix factorization of aerosol mass spectrometer data.

In particular, two specific aspects of our diagnostic evaluation provide new insights for CTMs improvement: i) this is one of the first works presenting a complete evaluation of all the main meteorological and chemical processes driving OA formation, also including a state-of-the-art chemical module like 1.5D-VBS; ii) this is the first time that model diagnostic evaluation is performed at regional scale over the Po Valley, a very challenging situation for its meteorological conditions and density of emission sources.

\section{Modelling setup}

\subsection{CAMx configuration and modelled domain}

We use CAMx 6.20 model (ENVIRON, 2015) to simulate dispersion phenomena and chemical processes. Homogenous gas phase reactions are reproduced through CB05 mechanism (Yarwood et al., 2005). The aerosol scheme is based on two static modes (coarse and fine). Secondary inorganic compounds evolution is described by thermodynamic algorithm ISORROPIA (Nenes et al., 1998). According to the main goal of the study, OA is separately simulated adopting both the algorithms available in CAMx: SOAP (Strader et al., 1999) and 1.5D-VBS (Koo et al., 2014).

145 The SOAP approach considers VOC gas-phase oxidation chemistry, forming condensable gases (CG), and equilibrium partitioning between condensable gas and secondary organic aerosol (SOA) for a number of CG/SOA pairs. Properties of CG/SOA pairs used in CAMx are described in ENVIRON (2015). 
sets for chemically aged oxygenated OA of anthropogenic (PAS) and biogenic (PBS) origin. Each basis set has five volatility bins ranging from 0 to $10^{3} \mu \mathrm{g} \mathrm{m}^{-3}$ in saturation concentration $\left(\mathrm{C}^{*}\right)$, where the first bin represents non-volatile $\mathrm{OA}$, while the others roughly cover the volatility range of semi-volatile organic compounds (SVOCs). Total OA is the sum of all OA in the five volatility bins from primary formation (POA $=\mathrm{PAP}+\mathrm{PFP})$ and from secondary formation $(\mathrm{SOA}=\mathrm{PAS}+\mathrm{PBS})$ sets.

This study is focused on a $580 \times 400 \mathrm{~km}^{2}$ area covering Northern Italy and including the Po Valley (the black rectangle in Figure 1). Model simulations are performed on a series of nested domains, thus adopting a proper spatial resolution in the inner domain, but preserving the overall simulation time. For the meteorological model WRF (Skamarock et al., 2008) three nested grids with different spatial resolution are used (Figure S.1). The largest grid (45 km resolution) covers Europe and Northern Africa, while the innermost domain corresponds to Italy and Po Valley with 15 and $5 \mathrm{~km}$ resolution, respectively. For CAMx simulations only the two innermost WRF nested grids were used.,. Simulations are performed for February 2013 in the framework of Regional "Supersito" project (Ricciardelli et al., 2017).

\section{$2.2 \quad$ Input data}

WE use the WRF model to reconstruct the hourly meteorological fields for CAMx. WRF runs cover two periods of 15 days each, with three additional days as spin-up. Initial and boundary conditions are derived from ECMWF analysis, available at ground level and at 13 different pressure levels (from 3 to $100 \mathrm{kPa}$ ), 4 times a day. The nudging technique is applied over the three model domains. CORINE land cover database (CORINE Land Cover 2006) produced by the European Environmental Agency is used instead of the default WRF land cover database developed by U.S. Geological Survey (USGS), The CORINE database is characterized by higher resolution and by more updated categories for land cover classification (Fedele et al., 2015). The WRFCAMx preprocessor is used to create CAMx ready input files collapsing the 29 vertical layers used by WRF into the 14 layers used by CAMx, but keeping identical the layers up to $1 \mathrm{~km}$ above ground level. In particular, the first layer height is around $25 \mathrm{~m}$. Input data also included ozone columnar content derived by OMI satellite data (http://toms.gsfc.nasa.gov). The initial and boundary concentrations for the first CAMx domain are obtained from the global model MOZART version 4.

Emissions of biogenic VOCs are estimated using the Model of Emissions of Gases and Aerosols from Nature (MEGAN version 2.03, Guenther et al., 2006), whereas the SEASALT model (version 3.1) based on Gong (2003) was used for estimating emissions of sea salt.

Anthropogenic emissions of gases and particles are derived from inventory data at three different levels: European Monitoring and Evaluation Programme data (EMEP, http://www.ceip.at/emission-datawebdab/emissions-used-in-emep-models/) available over a regular grid of 50x50 $\mathrm{km}^{2}$; ISPRA Italian national inventory data (http://www.sinanet.isprambiente.it/it/sia-ispra/inventaria/disaggregazione-dellinventarionazionale-2010) which provides a disaggregation for province; regional inventories data based on INEMAR methodology (INEMAR - ARPA Lombardia, 2015) for Lombardia, Piemonte and Veneto regions in the Po Valley, which provide detailed emissions data at municipality level. Hourly time patterns of the emissions were obtained by processing each emission inventory with the Sparse Matrix Operator for Kernel Emissions model (SMOKE v3.5) (UNC, 2013). Temporal disaggregation is based on monthly, daily and hourly profiles deduced by CHIMERE model (INERIS, 2006) and EMEP model from Institute of Energy Economics and the Rational Use of Energy (IER) project named GENEMIS (Pernigotti et al., 2013).

Input VOC species for the SOAP and 1.5D-VBS simulations are summarized in Supplementary Material Table S.1. For the two simulations VOCs emissions of volatile organic compounds are grouped in surrogate species and IVOCs (Intermediate Volatility Organic Compounds) and POA emissions are required by the 1.5D-VBS scheme.

As IVOC emissions are not included in emission inventories, a model-default factor 1.5xPOA is used as suggested by Robinson et al. (2007). POA emissions are split into the four species shown in Table S.1 (POA from gasoline, diesel, other anthropogenic sources, biomass burning) because in the ISPRA and INEMAR emission inventories the fuel used for SNAP categories number 2 (non industrial combustion) and 7 (road 
transport) is specified. Doubtful cases have been allocated in the category "other anthropogenic sources " as suggested in CAMx User Guide (ENVIRON, 2015).

\section{Environmental dataset} from the Regional Agency for Environmental Protection (ARPA) networks. Pressure, dew point, temperature, wind direction, wind speed and precipitation data from 110 SMAM ground level stations were collected. Data were measured every three hours according to the standards of the World Meteorological Organization (WMO). The dataset of ARPA data includes more than 300 stations in the whole domain (Fig. 1) but not all stations have measurements for all the parameters; moreover, only stations placed at less than $500 \mathrm{~m}$ a.s.l. were considered for domain-wide analysis. The number of selected stations available for each region and for each parameter is reported in Table 1.

Concentrations availability of atmospheric pollutants monitored by the regional environmental agencies are reported in Table 2. Only background stations are selected, in order to be comparable with modeled results at $5 \mathrm{~km}$ spatial resolution. The selected stations are categorized as Urban and Suburban (SBUB) and Rural (RB) sites.

During the study period OA characterization was performed at three sites (Ispra, Milano, and Bologna, see Fig. 1). Milano and Ispra are located in the Northern part of the study area while Bologna in the SouthEastern part. Ispra station $\left(45^{\circ} 28^{\prime} 43^{\prime \prime} \mathrm{N}, 9^{\circ} 13^{\prime} 56^{\prime \prime} \mathrm{E}\right)$, located at a rural background site affected by anthropogenic emissions (Gilardoni et al. 2011), is part of the European Monitoring and Evaluation Programme (EMEP). Milano station (Milano Pascal, 4528'43'N, 9¹3'56'E), representative of an urban background site (Milano population is about 1.2 millions), is part of the Italian Special Station program (Decree N. 299, 29.11.2012) set by the Italian transposition of EU Directive 2008/50/EC. Ispra and Milano sites provided daily observation of Elemental Carbon (EC), Organic Carbon (OC), nitrate, sulfate and ammonium referred to $\mathrm{PM}_{2.5}$ fraction. OC observations were converted to OA assuming an $\mathrm{OM} / \mathrm{OC}$ ratio = 1.7 (Aiken et al., 2008) also in agreement with a previous study performed over the Po Valley (Pirovano et al., 2015). In Milano OC and EC concentrations were measured with thermo-optical analysis of $\mathrm{PM}_{2.5}$ aerosol samples according to the NIOSH-Like protocol (more than 150 samples over the year 2013).

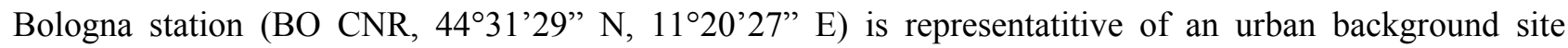
(Bologna population is about 0.4 millions). In Bologna, EC concentration was measured with thermo-optical analysis of $\mathrm{PM}_{2.5}$ aerosol samples (EUSAAR II method) (Poluzzi et al., 2015, Costa et al., 2016). PM concentration of nitrate, sulfate, ammonium, and OA were measured by Aerodyne high resolution time of flight aerosol mass spectrometer (HR-ToF-AMS) (DeCarlo et al., 2006), using composition dependent collection efficiency (Middlebrook et al., 2011). Concentrations were calculated from the analysis of high resolution of mass spectra acquired in V-mode (software SQUIRREL v1.51 and PIKA v1.10) with a time resolution of 5 minutes. Particles were dried with a Nafion drier at relative humidity below $30 \%$ prior to sampling. Data validation was performed by comparing sulfate, nitrate, and ammonium concentration from AMS analysis with the concentration measured by off-line ion chromatography on aerosol samples collected by Berner impactors. Analysis of OA mass spectra by means of Positive Matrix Factorization (PMF) allowed the separation of ambient urban OA mass into 5 factors: hydrocarbon-like OA (HOA), biomass burning OA (BBOA) and three types of oxygenated OA (OOA) (Gilardoni et al., 2016). HOA and BBOA are related to primary sources, whilst the three OOAs to secondary processes and thus regarded as a proxy of total SOA. HOA is linked with emissions from traffic and fossil fuel combustion, BBOA with biomass burning for residential heating. Among the three OOA factors, OOA1 was associated to the aqueous processing of biomass burning emissions (and so called also aqSOA) while OOA2 and OOA3 were linked to local fresher emissions (comprising again biomass burning products) and to very oxidized aerosols (typical of regional background), respectively. Both these latter factors are probably generated both by gas phase oxidation reactions not involving aqueous processing; therefore, hereinafter they are referred to as Dry SOA (DrSOA). 
Both the meteorological and chemical results were validated using the Atmospheric Model Evaluation Tool (AMET, Appel et al., 2011) that compares measured with modelled data through the bilinear interpolation of the modelled values at monitoring site coordinates. Several model performance parameters have been considered, namely: Mean Bias (MB), Mean Absolute Error (MAE), Index Of Agreement (IOA), and the Root Mean Square Error (RMSE), whose definition is reported in SM. MB and MAE provide a measure of the mean error between observed and modelled data; the former compensates between overestimations and underestimations, while the latter consider the absolute value of the error. Similar information can be inferred from RMSE, a widely used metric for model performance. Finally, IOA is a normalized measure of the agreement with respect to the temporal variability, like correlation, but taking into account also the influence of the error (Rao et al., 1985). Meteorological parameters were evaluated at both WMO and ARPA sites, but the presented results refer just to ARPA sites because performance was similar for the two datasets, but the latter included more stations and was based on hourly data.

CAMx provided the same results in both simulations for all species except for OA, and consequently for $\mathrm{PM}_{2.5}$ and $\mathrm{PM}_{10}$, because the change in the chemical scheme affected only OA. Therefore, in the following only one CAMx result is reported, except for $\mathrm{OA}, \mathrm{PM}_{2.5}$ and $\mathrm{PM}_{10}$.

Gas phase precursors were evaluated against hourly concentrations, $\mathrm{PM}_{10}$ and $\mathrm{PM}_{2.5}$ against daily concentrations. $\mathrm{PM}_{1}$ AMS data, averaged at 1-hour time resolution, were compared to modelled $\mathrm{PM}_{2.5}$ concentrations, because the adopted chemical scheme considers only a fine (0-2.5 $\mu \mathrm{m})$ and a coarse (2.5-10 $\mu \mathrm{m})$ bin. The decision to use PM1 observations for the comparison is due to the size range measured by the on-line instrumentation (the Aerodyne Aerosol Mass Spectrometer) that is below $1 \mu \mathrm{m}$. The comparison of modelled and observed aerosol concentrations referring to different size ranges could introduce an additional discrepancy to be taken into account, Particularly, in winter, when condensation processes are more relevant and the accumulation mode is shifted towards larger diameter, we expect that non-refractory species in $\mathrm{PM}_{1}$ fraction underestimate $\mathrm{PM}_{2.5}$ concentration by about $20 \%$.

The meteorological characterization of the simulation period and the model performance evaluation for gas phase precursors are described in the supplementary material (SM).

\subsection{Meteorological parameters}

Figure 2 shows the comparisons between the time patterns of the modelled and measured data at ARPA sites, averaged over the Po valley domain. Overall, looking at the whole month of February 2013, WRF is able to reproduce reasonably well most of the parameters, namely water vapour mixing ratio and temperature, while having some trouble with the snowfall events of February 11-12 and 21-22. The water vapour mixing ratio is slightly overestimated (MB $=0.2 \mathrm{~g} \mathrm{~kg}^{-1}, \mathrm{MAE}=0.25 \mathrm{~g} \mathrm{~kg}^{-1}$ ) with the largest departures from observation between February 7-10 (about $0.4 \mathrm{~g} \mathrm{~kg}^{-1}$ ) and February 14-21 (about $1 \mathrm{~g} \mathrm{~kg}^{-1}$ ). The temperature is overall slightly underestimated $(\mathrm{MB}=-0.45 \mathrm{deg}, \mathrm{MAE}=0.95 \mathrm{deg})$. The wind speed values observed and predicted are extremely low, never exceeding $6 \mathrm{~m} \mathrm{~s}^{-1}$; there isn't a prevalence of underestimation or overestimation $\left(\mathrm{MB}=0.08 \mathrm{~m} \mathrm{~s}^{-1}, \mathrm{MAE}=0.4 \mathrm{~m} \mathrm{~s}^{-1}\right)$ and the correlation is quite good $(\mathrm{IOA}=0.7)$. Global radiation is well predicted, especially in case of cloud cover during rainy events. However, it is generally overestimated (MB $\left.=78 \mathrm{~W} \mathrm{~m}^{-2}, \mathrm{MAE}=92 \mathrm{~W} \mathrm{~m}^{-2}\right)$. Rain is both overestimated and underestimated $\left(\mathrm{MB}=-0.036 \mathrm{~mm} \mathrm{~h}^{-1}, \mathrm{MAE}\right.$ $\left.=0.06 \mathrm{~mm} \mathrm{~h}^{-1}\right)$, so that this parameter had the lowest correlation between predictions and measurements $(\mathrm{IOA}=0.6)$.

\subsection{Particulate matter (PM 10 and $\left.P M_{2.5}\right)$, elemental carbon and inorganic aerosol compounds}

The model reconstructs the two fractions of PM with similar performances, as shown by the indices reported in Table 3. The best performance is obtained for $\mathrm{PM}_{2.5}$ at $\mathrm{RB}$ sites with SOAP scheme $(\mathrm{MB}=-1.7 \%, \mathrm{IOA}=$ $0.60, \operatorname{RMSE}=19.1 \mu \mathrm{g} \mathrm{m}^{-3}$ ), while the worst results are produced by VBS scheme for PM10 at SBUB sites $\left(\mathrm{MB}=-18.0 \%, \mathrm{IOA}=0.51, \mathrm{RMSE}=23.3 \mu \mathrm{g} \mathrm{m}^{-3}\right)$. CAMx slightly underestimates the monthly mean concentration at all sites, with the exception of SOAP scheme for $\mathrm{PM}_{10}$ at RB sites, where the model shows a positive bias around 5\%. At all sites the VBS scheme underestimates PM mass more than SOAP; however, IOA seems not influenced by the chemical scheme used. These findings are confirmed also by the inspection 
of the concentration time pattern (Figure 3), showing that SOAP scheme results are slightly higher than VBS, even though the models share the same temporal evolution. Figure 3 also shows that the model is not able to capture the PM mass peaks around February 11-23 (similar results are observed also for the main inorganic PM precursors, as shown in Figure S.5). A deeper insight on PM reconstruction with specific reference to $\mathrm{PM}_{2.5}$ and its main components has been performed for Ispra, Milano and Bologna sites. Since the number of sites is very limited, statistical indices and graphics are related to the three sites individually. Figure 4 to 7 show the comparison between observed and modelled concentrations of EC and of the three main inorganic components (sulfate, nitrate, ammonium); related statistical indices are reported in SM, from Table S.4 to Table S.7. The model slightly overestimates the EC concentration at Milano Pascal (mean modelled concentrations of $4.0 \mu \mathrm{g} \mathrm{m}^{-3}$, mean observed concentrations of $2.8 \mu \mathrm{g} \mathrm{m}^{-3}$ ); conversely, EC concentrations at Ispra and Bologna site are in better agreement with observations ( $\mathrm{MB}=0.02$ and $\mathrm{MB}=0.24 \mu \mathrm{g} \mathrm{m}^{-3}$, respectively). Measurements and model predictions for $\mathrm{SO}_{4}{ }^{=}$concentrations at Milano Pascal and Ispra matched very well $\left(\mathrm{MB}=0.7 \mu \mathrm{g} \mathrm{m}^{-3}\right.$ and $\mathrm{MB}$ $=0.2 \mu \mathrm{g} \mathrm{m}^{-3}$, respectively) with the only exception of the underestimation in the third week of the month. On the contrary, model predictions at Bologna are overestimated during all the month (mean modelled concentration of $4.5 \mu \mathrm{g} \mathrm{m}^{-3}$, mean observed concentration of $1.6 \mu \mathrm{g} \mathrm{m}^{-3}$ ). Also the temporal modulation is not well captured in Bologna: actually, the IOA index is 0.35 in Bologna and higher than 0.6 in Milano and Ispra. $\mathrm{SO}_{4}{ }^{=}$overestimation in Bologna is due to a few, very sudden peaks, with unrealistically high concentrations $\left(>15 \mu \mathrm{g} \mathrm{m}^{-3}\right.$ ), whose origin will be investigated furtherly. CAMx shows a similar performance for nitrate and for ammonium. The comparison between measured and modelled concentrations shows reasonable results both at Milano Pascal and Ispra, except for February 13-20, when the model underestimates, particularly at Milano site. Conversely, both species are systematically overestimated in Bologna. Mean observed concentrations for nitrate are $16 \mu \mathrm{g} \mathrm{m}^{-3}$ at Milano Pascal, $9 \mu \mathrm{g} \mathrm{m}{ }^{-3}$ at Ispra and $7 \mu \mathrm{g}$ $\mathrm{m}^{-3}$ at Bologna. Overall, the model underestimates nitrate concentrations both at Milano Pascal $(\mathrm{MB}=-6 \mu \mathrm{g}$ $\mathrm{m}^{-3}$ and $\left.\mathrm{MAE}=9 \mu \mathrm{g} \mathrm{m}^{-3}\right)$ and Ispra $\left(\mathrm{MB}=-3 \mu \mathrm{g} \mathrm{m}^{-3}\right.$ and $\left.\mathrm{MAE}=7 \mu \mathrm{g} \mathrm{m}^{-3}\right)$; however, such underestimation is mostly determined by the two peaks in mid-February missed by the model. Conversely, the model very frequently overestimates nitrate concentrations at Bologna (MB of $7 \mu \mathrm{g} \mathrm{m}^{-3}$ and MAE of $8 \mu \mathrm{g} \mathrm{m}^{-3}$ ). Coherently with nitrate and sulfate reconstruction, a small underestimation is shown also for ammonium at Milano Pascal $\left(\mathrm{MB}=-0.5 \mu \mathrm{g} \mathrm{m}{ }^{-3}\right.$ and $\left.\mathrm{MAE}=2 \mu \mathrm{g} \mathrm{m}^{-3}\right)$ and at Ispra $\left(\mathrm{MB}=-1.2 \mu \mathrm{g} \mathrm{m}^{-3}\right.$ and MAE $=2.3 \mu \mathrm{g} \mathrm{m}$ ${ }^{3}$ at Ispra), while overestimation is shown at Bologna (MB and $\mathrm{MAE}=3 \mu \mathrm{g} \mathrm{m}^{-3}$ ).

\subsection{Organic Aerosol}

Figure 8 reports the monthly mean contributions of POA (primary organic aerosol) and SOA (secondary organic aerosol) to the $\mathrm{PM}_{2.5}$ organic mass produced by CAMx in both runs (CAMx SOAP and CAMx VBS). POA concentration is about twice higher with SOAP scheme than with VBS: this is in agreement with the fact that SOAP considers POA as non-reactive. With the VBS scheme (Figure 8, bottom), fresh POA concentrations are relatively high (up to $7 \mu \mathrm{g} \mathrm{m}^{-3}$ ) in urban areas. SOA concentrations are lower and more homogeneous than POA, due to transport and dilution of gaseous precursors. VBS SOA concentration is higher than SOAP (up to $1 \mu \mathrm{g} \mathrm{m}^{-3}$ in the most urbanized areas), though the spatial pattern are similar. Figure 9 provides additional information about the origin of the OA simulated through VBS. The most relevant contribution to POA is produced by biomass burning, giving rise to BBOA concentrations ranging between 3 and $8 \mu \mathrm{g} \mathrm{m}^{-3}$ in the urban areas. The BBOA spatial distribution is clearly related to the corresponding fingerprint of the biomass burning emissions from residential heating. Differently, the HOA concentration is generally lower than $1 \mu \mathrm{g} \mathrm{m}^{-3}$, with maximum values in the largest cities (Torino, Milano), and along the main highways. Anthropogenic SOA (excluding biomass burning SOA) show higher concentrations than biogenic SOA, particularly in Southern Lombardia were SOAA mean concentration can reach $1 \mu \mathrm{g} \mathrm{m}^{-3}$. OA ambient concentrations (Figure 10) are widely underestimated by the SOAP simulation and even more by the VBS simulation for the whole month. OA mean bias at the three sites ranges between $-38 \%$ and $-60 \%$ for SOAP and between $-64 \%$ and $-75 \%$ for VBS scheme. Concentrations are underestimated along all month, particularly during the two high concentration episodes of February 3-6 and February 13-20, when observed OA concentrations at Ispra are higher than $30 \mu \mathrm{g} \mathrm{m}^{-3}$, while modelled values do not exceed $10 \mu \mathrm{g} \mathrm{m}^{-3}$. IOA is 
generally slightly above 0.5 for SOAP scheme, whereas IOA for VBS scheme can be lower than 0.5 , indicating that the model does not reproduce the temporal variation of observed OA. CAMx SOAP concentrations are always higher than the corresponding values produced by VBS, suggesting that the differences between the two performances are linked to the different schemes, and do not depend on different meteorological conditions or on emission strengths.

Figure 11 compares POA and SOA predicted by SOAP and the four components (HOA, BBOA, anthropogenic SOA, and biogenic SOA) predicted by VBS with the PMF factors observed in Bologna. It is important to point out that AMS factors refer to $\mathrm{PM}_{1}$ size range, while CAMx refers to $\mathrm{PM}_{2.5}$. The mean observed concentration for POA is $3.6 \mu \mathrm{g} \mathrm{m}^{-3}$, partially underestimated by the VBS scheme (MB $=-1.2 \mu \mathrm{g}$ $\mathrm{m}^{-3}$ and MAE $\left.=1.9 \mu \mathrm{g} \mathrm{m}^{-3}\right)$ and overestimated by the same amount by the SOAP scheme $\left(\mathrm{MB}=1.1 \mu \mathrm{g} \mathrm{m}^{-3}\right.$ and MAE $=2.6 \mu \mathrm{g} \mathrm{m}^{-3}$ ). Fig 11 panel $\mathrm{b}$ and $\mathrm{c}$ show that CAMx VBS predicts BBOA, the main fraction of POA, better than HOA: BBOA underestimation is less than $20 \%(\mathrm{IOA}=0.53)$, whereas the low bias for $\mathrm{HOA}$ is around $66 \%(\mathrm{IOA}=0.4)$. In addition CAMx simulates well the temporal variation of $\mathrm{BBOA}$, with the exception of a few peaks on February 8-11 and February 20-21. In Figure 11d the modelled SOA concentrations are compared with the sum of OOA factors from PMF, as a proxy of observed SOA. The VBS scheme predicts SOA concentrations 2 to 5 times higher than the SOAP scheme. However, both schemes still underestimate SOA concentrations (monthly mean $=4.5 \mu \mathrm{g} \mathrm{m}^{-3}$ ) with a bias of $-3.8 \mu \mathrm{g} \mathrm{m}^{-3}(-$ $83 \%)$ and $-4.3 \mu \mathrm{g} \mathrm{m}^{-3}(-93 \%)$, respectively. Observed SOA can be decomposed in one factor (OOA1) formed through aqueous phase processing of organic aerosol in wet particles, and two factors (OOA2 and OOA3) corresponding to SOA formed from gas-phase oxidation and processing. Since both SOAP and VBS schemes neglect SOA formation in aqueous phase, a more accurate comparison is reported in Figure 11e, where CAMx SOA are displayed against DrSOA (obtained by the sum of OOA2 and OOA3). The removal of the aqSOA from SOA budget improves model performance with decreasing bias (from $-83 \%$ to $-74 \%$ ) and increasing IOA (from 0.48 to 0.52 ). Although CAMx results still widely underestimate DrSOA (Table 5), this result suggest that including wet aerosol chemistry might help to reduce the discrepancy between modeled and observed SOA.

\section{Discussion}

One of the common features of the CAMx results is the systematic underestimation of both gas and aerosol concentrations taking place in the middle of February. As the underprediction of these peak events affects both gaseous precursors and PM, regardless for the modelling scheme adopted (i.e. SOAP or VBS), it might be linked to limitation in the meteorological simulation and not to the SOA formation and ageing. As discussed in S.M., such period was characterized by a snowfall episode (February 11-12) followed by the development of more stagnant conditions (Figure S.9). The discrepancy between modelled and observed concentrations is clearly described in Figure S.10 and S.11, showing the comparison between modelled and observed $\mathrm{NO}_{\mathrm{X}}$ and $\mathrm{NO}_{2}$ concentrations. Model underestimation occurs over the whole domain, but particularly in the Alpine foothill areas (Figure S.12). This is confirmed also by the comparison between hilly and plain sites shown in Figure S.16. The model underestimation is probably related to a wrong reconstruction of the Planetary Boundary Layer (PBL) height during that period. Indeed, as shown in Figure S.18, WRF simulates a higher PBL height at foothills than in the plain area, while the spatial distribution of a primary pollutant such as $\mathrm{NO}_{\mathrm{X}}$ (Figure S.12) seems suggesting the opposite. The incorrect reconstruction of PBL height is probably related to a corresponding overestimation of wind speed and related mechanical turbulence. As shown in Figure S.14, WRF reproduces correctly the development of the temperature field, while it overestimates wind speed at hilly areas. Such discrepancy is the likely cause of the PBL overestimation, as it can be inferred from Figure S.15 showing that in the hilly region PBL height is mainly driven by wind speed, particularly during night-time and early-morning hours.

The analysis of the modelled PBL height over the whole month at hilly and plain sites shows two additional and interesting features: the first one is that the meteorological model is able to follow the development of different dispersion conditions along the whole month, correctly simulating low PBL heights during stable conditions (middle of February) and more diffusive conditions during unstable periods (e.g. February 7-10), but it is not able to completely capture the features of the strongest accumulation conditions. The second 
feature is that WRF tends to simulate a higher PBL height over hilly areas than plain areas, particularly during night-time, pointing out a systematic behavior in WRF, not depending on specific meteorological conditions. A more general consequence that can be ascribed to the influence of meteorological model performance is that WRF favors the accumulation of pollutants in the plain areas while concentrations could be more strongly underestimated close to foothill areas. This feature seems particularly clear during strong stagnation conditions. This can have an influence on both primary aerosol components, such as EC (see February 13-18 in Figure 4), but also on secondary PM. Indeed, as shown in Figure 6 and 7, nitrate and ammonium concentrations are overestimated at Bologna site, while they are correctly reproduced at Ispra and Milano, except for middle February, when CAMx clearly underestimates. This result is confirmed also by the analysis of $\mathrm{NH}_{3}$ concentration (Figure S.7) that are frequently overestimated in Bertonico (placed in South of Lombardia) whereas in Milano $\mathrm{NH}_{3}$ is more frequently underestimated, particularly during the February 13-18 episode. This result indicates that the strong underestimation of OA in Ispra and Milano cannot be ascribed exclusively to lack in emissions or chemical processes, but is partially driven by meteorology. A further effect of the influence of the meteorological input can be observed between February 22-27 when PM was overestimated by the model (Figure 3). This discrepancy may be linked to the underestimation of rain by WRF during those periods as shown in Figure 2.

Besides of meteorology also uncertainty in emission reconstruction can affect modelled results. As shown in Figure 5, sulfate concentration is correctly reproduced in Ispra and Milano, while it is overestimated in Bologna. Overestimation takes place particularly during night-time hours and could be related to an overestimation of ground level $\mathrm{SO}_{2}$ emissions in Emilia Romagna region. As depicted in Figure S.2 groundlevel diffuse emissions of $\mathrm{SO}_{2}$ in Emilia Romagna are generally higher than in the surrounding regions and this is a feature specific to $\mathrm{SO}_{2}$ which is not reflected by the other pollutants. During proper meteorological conditions, such as stagnation with high relative humidity levels, $\mathrm{SO}_{2}$ can easily transform into sulphate giving rise to the overestimation observed in Bologna. This finding confirms the critical role of emission inventory estimates. A second source of uncertainty related to emissions stems from chemical speciation profiles. A first example of such influence is elemental carbon. EC is a product of incomplete combustion that can be emitted by traffic, fossil fuels, biomass burning and industry. As shown in Figure 4 and Table S.3, EC is frequently overestimated at all sites, with the exception of middle February, likely due to an error compensation with meteorology. The overestimation is stronger at the urban site of Milano than at the rural site of Ispra, suggesting that the traffic EC used as input in CAMx should be lowered.

The analysis of AMS data showed that POA represents about $45 \%$ of the OA total mass. The result is similar to what observed at European level for winter season by Ciarelli et al. (2017) where POA accounted for 38\% of OA. The slightly higher contribution observed in the Po valley can be due to the stronger stagnation conditions favoring the accumulation of the primary PM fraction, particularly in the urban context. The relative apportionment between POA and SOA is not correctly reproduced by CAMx that shows a primary fraction of $96 \%$ and $77 \%$ for SOAP and VBS, respectively, due to a strong underestimation of secondary OA. The underestimation of the SOA fraction during wintertime has been pointed out also by Fountoukis et al (2016) for the city of Paris, confirming that there is a general lack in the reconstruction of processes forming secondary OA in a polluted environment with high NOx concentrations and low photochemical activity. The effect of possible uncertainties in emission inventories and chemical speciation profiles, already discussed for gas phase species, can be relevant also for OA. Focusing on POA, as shown in Figure 11b-g and Figure 11c-h, CAMx is able to capture the contribution of BBOA, while it underestimates HOA. The contribution of biomass burning to primary $\mathrm{OA}$ is correctly reproduced during daytime, when the model shows just a slight overestimation on the early morning hours, likely due to a not accurate emission temporal profile. In contrast, BBOA is underestimated during night hours, but this could depend on a partial overestimation of PBL height. HOA concentrations are underestimated all day long and, particularly, the model is missing the rush hour increase. These results suggest that POA emissions related to road transport are either underestimated or associated to higher volatility classes, as already discussed by Fountoukis et al., (2014). This result seem confirmed also comparing the differences in model performance between SOAP and VBS. Indeed, CAMx results show that the reduction in POA concentration moving from SOAP to VBS 
(from 4.7 to $2.4 \mu \mathrm{g} \mathrm{m}^{-3}$ ) is not compensated by a corresponding increase in SOA concentration, rising from 0.17 to $0.73 \mu \mathrm{g} \mathrm{m}^{-3}$.

The clear degradation in model performance, observed when moving from POA to SOA, proves that the strong discrepancy between modelled and observed OA concentration is mainly due to limitations in the chemical algorithms and source characterization for OA atmospheric evolution. VBS can lead in some cases to a partial reduction of the model bias, due to several reasons: POA evaporation feeding SOA formation, introduction of additional emissions (IVOC), and improved description of SOA volatility in terms of volatility bins each having an explicit aging pathway. However, the large underestimation of SOA shown in Figure 10d-i confirms that there are still relevant gaps to be filled in OA modelling that could be linked to each of the previous items. A first limitation of the actual OA modelling schemes is related to the absence of chemical pathways producing SOA through VOC oxidation in aqueous phase. The analysis of OOA factors showed that on average about $30 \%$ of the total observed SOA derives from oxidation processes in heterogeneous phase (Table 5), but this fraction can be even higher (e.g. February 13-16, see Figure 11d and 11e). The relevance of aqueous-phase SOA was remarked by previous studies. Gilardoni et al (2016) provided a first observational estimate of SOA produced by aqueous-phase processing of wood smoke particles in Europe: 0.1 to $0.5 \mathrm{Tg}$ of organic carbon per year, corresponding to $4-20 \%$ of total primary organic aerosol emissions in the region. The still lacking representation of aqSOA is therefore one of the imputed reasons of the model-observation discrepancy. For example, Carlton et al. (2008) observed that including aqueous phase reactions can significantly reduce OC underestimation. They estimated that in presence of clouds layer, the modelled OC from aqueous reactions can be doubled. Moreover including aqueous SOA can increase the monthly averaged regional OC concentration up to $20 \%$.

However, even neglecting the SOA fraction related to aqueous processes, the lack between modelled and observed concentrations is still relevant, as shown in Figure 11e. The analysis of the secondary organic fractions reveals that CAMx underestimates the contribution of both fossil fuels and biomass burning sources. Comparing the hourly time series of SOA, OOA2 and OOA3, as well as the mean day of the same species (Figure 11i, j) it is worth noting that their atmospheric fate seems driven by different processes. Indeed, SOA and OOA3 show quite flat hourly profiles, while their day-to-day variation reflects the development of the different stagnation and dispersion conditions. This suggests that the total burden of modelled SOA is more influenced by aging processes, taking place over time scales of several days, than the temporal variation of emission sources.. The underestimation of semi-volatile emissions as well as of the strength of the aging process can be reasons of CAMx underestimation. In contrast, the sub-fraction of SOA directly linked to biomass burning (OOA2) presents a very clear daily cycle and seems less influenced by the evolution of the meteorological conditions. This points out that the formation of SOA from wood burning emissions could be driven by faster processes, more closely related to the availability of OA precursors. Missing precursors in CAMx could be a reason of model underestimation of this fraction.

\section{Conclusions}

The aerosol concentration in the Po Valley was modelled with the regional air quality model CAMx implementing two different schemes (SOAP and 1.5D-VBS) for organic aerosol reconstruction. Model simulations considered February 2013 as a case study. Although the model well simulates inorganic aerosol, regardless of the partitioning/aging approach (SOAP or VBS) used for OA, PM mass concentrations are systematically under predicted both by CAMx-SOAP and by CAMx-VBS, due to underestimation of OA. In order to investigate OA model performance, the VBS simulation predictions were compared with factoranalysis of the Aerosol Mass Spectrometer (AMS) data for one monitoring site.

Even though limited to a rather short winter period, the main conclusions stemming from these simulations and comparisons with observations are as follows:

- Meteorological fields were reasonably reproduced by the meteorological model WRF. However, the model showed some limitations in the reproduction of some specific features (e.g. the PBL evolution in foothill areas) that can lead to relevant discrepancies between the predicted and the observed PM mass, as shown by the strong PM underestimation during a few episodes in the period of this study. 
- Limitations in meteorological fields can explain a large part of CAMx discrepancies in reproducing gas phase precursors and inorganic aerosol, but they can elucidate only to a lesser extent CAMx performance for organic aerosol.

- CAMx performance for OA is clearly better for the primary than secondary fraction

- For total OA (i.e.: POA + SOA) SOAP scheme provides better results than VBS, because POA fraction is overestimated, thus partially compensating the SOA underestimation. In the SOAP simulation the predicted POA fraction is higher than the one derived from CAMx-VBS because the SOAP approach does not take into account the volatility of POA

- Overall the VBS scheme seems to give more realistic estimates for the different fractions of OA. These results support the idea that many processes neglected in the SOAP scheme are important (e.g.: oxidation of intermediate to low volatility organic compounds, partitioning of POA, and the oxidation and fragmentation pathways).

- POA fraction related to biomass burning is better reproduced than HOA, pointing out either a underestimation of organic emissions from road transport or an overestimation of the volatility.

- The underestimation of SOA can be related to several shortcomings in both emissions and process description. A first finding that stems from PMF analysis is that in the Po valley a relevant fraction of OA is produced by heterogeneous phase processes, probably driven by fog, that so far are totally missing in the chemical scheme. Secondly, the model seems unable to correctly capture the faster intra-day processes that characterize the daily evolution of SOAB as well as the slower aging processes that rule the $\mathrm{OA}$ accumulation over longer periods. The underestimation of the former processes could be related to an underestimation of SVOC emissions from domestic heating that can contribute to SOAB formation processes over a rather short time-scale, as underlined by Ciarelli et al. (2015). On the other hand, the underestimation of aging processes could be ascribed both the chemical mechanism and particularly to the strength of the oxidation processes that could take place at high NOx concentrations and low photochemical activity (Fountoukis et al., 2016) as well as to an underestimation of the gas phase precursors, such as IVOCs that are highly uncertain and the can affect the amount of the available oxidants (Tsimpidi et al., 2010).

In more general terms we can affirm that the results obtained in this work confirmed several findings of previous studies, but with a specific focus on the Po valley, an area where local and regional meteorology influence air quality processes no less than local and regional emissions sources (Ricciardelli et al., 2017). This allowed to investigate the influence of such peculiar features on OA modelling, with respect to previous studies mainly dealing with the European scale. Particularly, the presence of frequent stagnation conditions can: i) amplify the effect of errors in the emission inventories, as in case of the HOA fraction; ii) increase the influence of IVOC/SVOC emission underestimation on OA formation through aging processes; iii) enhance the role of heterogeneous phase processes, mainly driven by fog.

Moreover, the sensitivity analysis of the OA modules indicates that CAMx $1.5 \mathrm{D}-\mathrm{VBS}$ is a very promising approach in describing OA concentration and composition, although there are still relevant limitations and uncertainties to be further investigated. First, this VBS scheme requires a number of assumptions concerning the volatility, reaction rates and oxygen gain at each oxidation step, that are partially depending on each case study, but that are very difficult to identify. Consequently, parameters available in literature are often used. Additional sensitivity studies of the VBS setup are therefore required, in order to assess the actual sensitivity of the modelled results to the input setup. A second recommendation for future research concern emissions. Particularly, improved estimations of the amounts and speciation of primary SVOCs and IVOCs as well as more specific measurements of the sources of SOA are needed to further constrain and evaluate the model results. Additional research should also be carried out in order to improve the reproduction of aqueous-phase processes, above all in presence of fog. Last but not least, performing the comparison of the modeled concentrations with filter-based PM speciated data and with AMS data from a larger number of monitoring sites, both collected in the different seasons of the year, would give a great impact to evaluate the model performance.

Finally, the application of the 1.5D-VBS should be extended also to a summer case. Because the oxidation processes in winter and in summer are different and SOA formation with high temperatures is very 
important, due to the faster chemical aging, a summer simulation may give further enhancement in the evaluation of VBS scheme, also allowing a better evaluation of the role played by biogenic VOC emissions, whose influence is very limited during the cold season.

\section{References}

Aiken, A.C., DeCarlo, P.F., Kroll, J.H., Worsnop, D.R., Huffman, J.A., Docherty, K.S., Ulbrich, I.M., Mohr, C., Kimmel, J.R., Sueper, D., Sun, Y., Zhang, Q., Trimborn, A., Northway, M., Ziemann, P.J., Canagaratna, M.R., Onasch, T.B., Alfarra, M.R., Prevot, A.S.H., Dommen, J., Duplissy, J., Metzger, A., Baltensperger, U., Jimenez, J.L. (2008). $\mathrm{O}=\mathrm{C}$ and $\mathrm{OM} / \mathrm{OC}$ ratios of primary, secondary, and ambient organic aerosols with high-resolution time-of-flight aerosol mass spectrometry, Environmental Science \& Technology, 42, 4478-4485.

Appel, K.W., Gilliam, R.C., Davis, N., Zubrow, A., Howard, S.C. (2011). Overview of the atmospheric model evaluation tool (AMET) v1.1 for evaluating meteorological and air quality models, Environmental Modelling \& Software, 26, 434-443, ISSN 1364-8152, http://dx.doi.org/10.1016/j.envsoft.2010.09.007.

Bergström, R., Denier van der Gon, H.A.C., Prévôt, A.S.H., Yttri, K.E., Simpson, D. (2012). Modelling of organic aerosols over Europe (2002-2007) using a volatility basis set (VBS) framework: application of different assumptions regarding the formation of secondary organic aerosol, Atmospheric Chemistry and Physics, 12, 8499-8527.

Carlton, A.G., Turpin, B.J., Altieri, K.E., Seitzinger, S.P., Mathur, R., Roselle, S.J., Weber, R.J. (2008). CMAQ model performance enhanced when in-cloud SOA is included: Comparisons of OC predictions with measurements. Environmental Science \& Technology, 42, 8798-8802.

Ciarelli, G., Aksoyoglu, S., Crippa, M., Jimenez, J.L., Nemitz, E., Sellegri, K., Äijälä, M., Carbone, S., Mohr, C., O'Dowd, C., Poulain, L., Baltensperger, U., Prévôt, A.S.H (2015). European air quality modelled by CAMx including the volatility basis set scheme, Atmospheric Chemistry and Physics Discussion, 15, 35645-35691.

Ciarelli, G., Aksoyoglu, S., El Haddad, I., Bruns, E. A., Crippa, M., Poulain, L., Äijälä, M., Carbone, S., Freney, E., O'Dowd, C., Baltensperger, U., Prévôt, A.S.H. (2017). Modelling winter organic aerosol at the European scale with CAMx: evaluation and source apportionment with a VBS parameterization based on novel wood burning smog chamber experiments, Atmospheric Chemistry and Physics, 17, 7653-7669, https://doi.org/10.5194/acp-17-7653-2017.

Costa, V., Bacco, D., Castellazzi, S., Ricciardelli, I., Vecchietti, R., Zigola, C., Pietrogrande, M.C. (2016). Characterization of carbonaceous aerosol in Emilia Romagna during the Supersito Project: influences of the Thermal-Optical measurement protocols, Atmospheric Research, 167, 100-107.

Crippa, M., DeCarlo, P.F., Slowik, J.G., Mohr, C., Heringa, M.F., Chirico, R., Poulain, L., Freutel, F., Sciare, J., Cozic, J., Di Marco, C.F., Elsasser, M., Nicolas, J. B., Marchand, N., Abidi, E., Wiedensohler, A., Drewnick, F., Schneider, J., Borrmann, S., Nemitz, E., Zimmermann, R., Jaffrezo, J.-L., Prévôt, A.S.H., Baltensperger, U. (2013). Wintertime aerosol chemical composition and source apportionment of the 
organic fraction in the metropolitan area of Paris, Atmospheric Chemistry and Physics, 13, 961-981, doi:10.5194/acp-13-961-2013.

Crippa, M., Canonaco, F., Lanz, V. A., Äijälä, M., Allan, J.D., Carbone, S., Capes, G., Ceburnis, D., Dall'Osto, M., Day, D.A., DeCarlo, P.F., Ehn, M., Eriksson, A., Freney, E., Hildebrandt Ruiz, L., Hillamo, R., Jimenez, J.L., Junninen, H., Kiendler-Scharr, A., Kortelainen, A.-M., Kulmala, M., Laaksonen, A., Mensah, A.A., Mohr, C., Nemitz, E., O'Dowd, C., Ovadnevaite, J., Pandis, S.N., Petäjä, T., Poulain, L., Saarikoski, S., Sellegri, K., Swietlicki, E., Tiitta, P., Worsnop, D.R., Baltensperger, U., Prévôt, A.S.H. (2014). Organic aerosol components derived from 25 AMS data sets across Europe using a consistent ME2 based source apportionment approach, Atmospheric Chemistry and Physics, 14, 6159-6176, doi:10.5194/acp-14-6159-2014.

DeCarlo, P.F., Kimmel, J.R., Trimborn, A., Northway, M.J., Jayne, J.T., Aiken, A.C., Gonin, M., Fuhrer, K., Horvath, T., Docherty, K.S., Worsnop, D.R., Jimenez, J.L. (2006). Field-deployable, high-resolution, timeof-flight aerosol mass spectrometer, Analytical Chemistry, 78, 8281-8289.

Denier van der Gon, H. A.C., Bergström, R., Fountoukis, C., Johansson, C., Pandis, S.N., Simpson, D., Visschedijk, A.J.H. (2015). Particulate emissions from residential wood combustion in Europe - revised estimates and an evaluation, Atmos. Chem. Phys., 15, 6503-6519, https://doi.org/10.5194/acp-15-65032015 ,

Donahue, N.M., Robinson, A.L. Stanier, C.O., Pandis, S.N. (2006). Coupled partitioning, dilution, and chemical aging of semivolatile organics, Environmental Science \& Technology, 40, 2635-2643.

Donahue, N.M., Robinson, A.L., Pandis, S.N. (2009). Atmospheric organic particulate matter: from smoke to secondary organic aerosol, Atmospheric Environment, 43, 94-106.

Donahue, N.M., Epstein, S.A., Pandis, S.N., Robinson, A.L. (2011). A two-dimensional volatility basis set: 1. organic-aerosol mixing thermodynamics, Atmospheric Chemistry and Physics, 11, 3303-3318.

Donahue, N.M., Kroll, J.H., Pandis, S.N., Robinson, A.L. (2012). A two-dimensional volatility basis set-part 2: Diagnostics of organic-aerosol evolution, Atmospheric Chemistry and Physics, 12, 615-634.

EEA, 2016. Air quality in Europe - 2016 report. EEA Report No 28/2016

ENVIRON (2015). CAMx (Comprehensive Air Quality Model with extensions) User's Guide Version 6.2. ENVIRON International Corporation, Novato, CA.

Fedele, F., Miglietta, M.M., Perrone, M.R., Burlizzi, P., Bellotti, R., Conte, D., Guarnieri Calò Carducci, A. (2015). Numerical simulations with the WRF model of water vapour vertical profiles: A comparison with LIDAR and radiosounding measurements, Atmospheric Research, 166, 110-119.

Fountoukis, C., Racherla, P.N., Denier van der Gon, H.A.C., Polymeneas, P., Charalampidis, P.E., Pilinis, C., Wiedensohler, A., Dall'Osto, M., O'Dowd, C., Pandis, S.N. (2011). Evaluation of a three-dimensional chemical transport model (PMCAMx) in the European domain during the EUCAARI may 2008 campaign, Atmospheric Chemistry and Physics, 11, 10331-10347.

Fountoukis, C., Megaritis, A.G., Skyllakou, K., Charalampidis, P.E., Pilinis, C., Denier van der Gon, H.A.C., Crippa, M., Canonaco, F., Mohr, C., Prévôt, A.S.H., Allan, J.D., Poulain, L., Petäjä, T., Tiitta, P., Carbone, S., Kiendler-Scharr, A., Nemitz, E., O'Dowd, C., Swietlicki, E., Pandis, S.N. (2014). Organic aerosol concentration and composition over Europe: insights from comparison of regional model predictions with aerosol mass spectrometer factor analysis, Atmospheric Chemistry and Physics, 14, 9061-9076, doi:10.5194/acp-14-9061-2014

Fountoukis, C., Megaritis, A.G., Skyllakou, K., Charalampidis, P.E., Denier van der Gon, H.A.C., Crippa, M., Prévôt, A.S.H., Fachinger, F., Wiedensohler, A., Pilinis, C., Pandis, S.N. (2016). Simulating the formation of carbonaceous aerosol in a European Megacity (Paris) during the MEGAPOLI summer and winter campaigns, Atmospheric Chemistry and Physics, 16, 3727-3741, doi:10.5194/acp-16-3727-2016.

Fuzzi, S., Baltensperger, U., Carslaw, K., Decesari, S., Denier van der Gon, H.A.C., Facchini, M.C., Fowler, D., Koren, I., Langford, B., Lohmann, U., Nemitz, E., Pandis, S.N., Riipinen, I., Rudich, Y., Schaap, M., Slowik, J.G., Spracklen, D.V., Vignati, E., Wild, M., Williams, M., Gilardoni, S. (2015). Particulate matter, 
air quality and climate: lessons learned and future needs, Atmospheric Chemistry and Physics, 15, 82178299, doi:10.5194/acp-15-8217-2015.

Gilardoni, S., Vignati, E., Cavalli, F., Putaud, J.P., Larsen, B. R., Karl, M., Stenström, K., Genberg, J., Henne, S., Dentener, F. (2011). Better constraints on sources of carbonaceous aerosols using a combined $14 \mathrm{C}$ - macro tracer analysis in a European rural background site, Atmospheric Chemistry and Physics, 11, 5685-5700, doi:10.5194/acp-11-5685-2011.

Gilardoni, S., Massoli, P., Giulianelli, L., Rinaldi, M., Paglione, M., Pollini, F., Lanconelli, C., Poluzzi, V., Carbone, S., Hillamo, R., Russell, L.M., Facchini, M.C., Fuzzi, S. (2014). Fog scavenging of organic and inorganic aerosol in the Po Valley, Atmospheric Chemistry and Physics, 14, 6967-6981, doi:10.5194/acp14-6967-2014, 2014.

Gilardoni, S., Massoli, P., Paglione, M., Giulianelli, L., Carbone, C., Rinaldi, M., Decesari, S., Sandrini, S., Costabile, F., Gobbi, G.P., Pietrogrande, M.C., Visentin, M., Scotto, F., Fuzzi, S., Facchini, M.C. (2016). Direct observation of aqueous secondary organic aerosol from biomass-burning emissions, PNAS 113, 10013-10018.

Godowitch, J.M., Gilliam, R.C., Rao, S.T. (2011). Diagnostic evaluation of ozone production and horizontal transport in a regional photochemical air quality modeling system, Atmospheric Environment, 45, 39773987. https://doi.org/10.1016/j.atmosenv.2011.04.062.

Gong, S.L., 2003. A parameterization of sea-salt aerosol source function for sub- and super-micron particles. Global Biogeochemical Cycles 17, 1097-1104.

Guenther, A., Karl, T., Harley, P., Wiedinmyer, C., Palmer, P.I., Geron, C. (2006). Estimates of global terrestrial isoprene emissions using MEGAN (Model of Emissions of Gases and Aerosols from Nature). Atmospheric Chemistry and Physics, 6, 3181-3210.

Hallquist, M., Wenger, J.C., Baltensperger, U., Rudich, Y., Simpson, D., Claeys, M., Dommen, J., Donahue, N.M., George, C., Goldstein, A.H., Hamilton, J. F., Herrmann, H., Hoffmann, T., Iinuma, Y., Jang, M., Jenkin, M.E., Jimenez, J.L., Kiendler-Scharr, A., Maenhaut, W., McFiggans, G., Mentel, Th.F., Monod, A., Prévôt, A.S.H., Seinfeld, J.H., Surratt, J.D., Szmigielski, R., Wildt, J. (2009). The formation, properties and impact of secondary organic aerosol: current and emerging issues, Atmospheric Chemistry and Physics, 9, 5155-5236, https://doi.org/10.5194/acp-9-5155-2009.

Heald, C.L., Kroll, J.H, Jimenez, J.L., Docherty, K.S., DeCarlo, P.F. , Aiken, A.C., Chen, Q., Martin, S.T., Farmer, D.K., Artaxo, P. (2010) A simplified description of the evolution of organic aerosol composition in the atmosphere, Geophysical Research Letters, 37, L08803.

INEMAR - Arpa Lombardia (2015), INEMAR, Emission Inventory: 2012 emission in Region Lombardy public review. ARPA Lombardia Settore Aria. Available at: http://www.inemar.eu/

INERIS, 2006. Documentation of the chemistry-transport model CHIMERE [version V200606A]. Available at: http://euler.lmd.polytechnique.fr/chimere/

Jimenez, J.L., Canagaratna, M.R., Donahue, N.M., Prevot, A.S., Zhang. Q,, Kroll. J,H,, De Carlo. P,F, Allan, J.D., Coe, H., Ng, N.L., Aiken, A.C., Docherty, K.S., Ulbrich, I.M., Grieshop, A.P., Robinson, A.L., Duplissy, J., Smith, J.D., Wilson, K.R., Lanz, V.A., Hueglin, C., Sun, Y.L., Tian, J., Laaksonen, A., Raatikainen, T., Rautiainen, J., Vaattovaara, P., Ehn, M., Kulmala, M., Tomlinson, J.M., Collins, D.R., Cubison, M.J., Dunlea, E.J., Huffman, J.A., Onasch, T.B., Alfarra, M.R., Williams, P.I., Bower, K., Kondo, Y., Schneider, J., Drewnick, F., Borrmann, S., Weimer, S., Demerjian, K., Salcedo, D., Cottrell, L., Griffin, R., Takami, A., Miyoshi, T., Hatakeyama, S., Shimono, A., Sun, J.Y., Zhang, Y.M., Dzepina, K., Kimmel, JR., Sueper, D., Jayne, J.T., Herndon, S.C., Trimborn, A.M., Williams, L.R., Wood, E.C., Middlebrook, A.M., Kolb, C.E., Baltensperger, U., Worsnop, D.R. (2009). Evolution of organic aerosols in the atmosphere, Science, 326(5959), 1525-1529.

Koo, B., Knipping, E., Yarwood, G. (2014). 1.5-Dimensional volatility basis set approach for modeling organic aerosol in CAMx and CMAQ, Atmospheric Environment, 95, 158-164. 
Lane, T.E., Donahue, N.M., Pandis, S.N. (2008). Simulating secondary organic aerosol formation using the volatility basis-set approach in a chemical transport model, Atmospheric Environment, 42, 7439-7451.

Larsen, B.R., Gilardoni, S., Stenström, K., Niedzialek, J., Jimenez, J.L., Belis, C.A. (2012). Sources for PM air pollution in the Po Plain, Italy: II. probabilistic uncertainty characterization and sensitivity analysis of secondary and primary sources, Atmospheric Environment, 50, 203-213, doi:10.1016/j.atmosenv.2011.12.038.

Lonati, G., Pirovano, G., Sghirlanzoni, G.A., Zanoni, A. (2010). Speciated fine particulate matter in Northern Italy: a whole year chemical and transport modelling reconstruction. Atmospheric Research 95, 496-514.

Middlebrook, A.M., Bahreini, R., Jimenez, J.L., Canagaratna, M.R. (2011). Evaluation of compositiondependent collection efficiencies for the aerodyne aerosol mass spectrometer using field data, Aerosol Science and Technology, 46, 258-271.

Mohr, C., DeCarlo, P.F., Heringa, M.F., Chirico, R., Slowik, J.G., Richter, R., Reche, C., Alastuey, A., Querol, X., Seco, R., Peñuelas, J., Jiménez, J.L., Crippa, M., Zimmermann, R., Baltensperger, U., Prévôt, A.S.H. (2012). Identification and quantification of organic aerosol from cooking and other sources in Barcelona using aerosol mass spectrometer data, Atmospheric Chemistry and Physics, 12, 1649-1665, doi:10.5194/acp-12-1649-2012.

Murphy, B.N., Donahue, N.M., Fountoukis, C., Dall'Osto, M., O’Dowd, C., Kiendler-Scharr, A., Pandis, S.N. (2012). Functionalization and fragmentation during ambient organic aerosol aging: application of the 2-D volatility basis set to field studies, Atmospheric Chemistry and Physics, 12, 10797-10816, doi:10.5194/acp-12-10797-2012.

Nenes, A, Pilinis, C., Pandis, S.N. (1998). ISORROPIA: A New Thermodynamic Model for Multiphase Multicomponent Inorganic Aerosols. Aquatic Geochemistry, 4, 123-152.

Ng, N.L., Canagaratna, M.R., Zhang, Q., Jimenez, J.L., Tian, J., Ulbrich, I.M., Kroll, J.H., Docherty, K.S., Chhabra, P.S., Bahreini, R., Murphy, S.M., Seinfeld, J.H., Hildebrandt, L., Donahue, N.M., DeCarlo, P.F., Lanz, V.A., Prévôt, A.S.H., Dinar, E., Rudich, Y., Worsnop, D.R. (2010). Organic aerosol components observed in Northern Hemispheric datasets from Aerosol Mass Spectrometry, Atmospheric Chemistry and Physics, 10, 4625-4641, doi:10.5194/acp-10-4625-2010.

Odum, J.R., Hoffmann, T., Bowman, F. Collins, D., Flagan, R.C, Seinfeld, J.H. (1996). Gas/particle partitioning and secondary organic aerosol yields. Environmental Science and Technology, 30, 2580-2585.

Pankow, J. (1994). An Absorption Model of Gas/Particle partitioning of organic compounds in the atmosphere, Atmospheric Environment, 28, 185-188.

Pernigotti, D., Thunis, P., Cuvelier, C., Georgieva, E., Gsella, A., De Meij, A., Pirovano, G., Balzarini, A., Riva, G.M., Carnevale, C., Pisoni, E., Volta, M., Bessagnet, B., Kerschbaumer, A., Viaene, P., De Ridder, K., Nyiri, A., Wind, P. (2013). POMI: a model inter-comparison exercise over the Po Valley. Air Quality, Atmosphere \& Health. http://dx.doi.org/10.1007/s11869-013-0211-1.

Pirovano, G., Colombi, C., Balzarini, A., Riva, G.M., Gianelle, V., Lonati, G. (2015). PM2.5 source apportionment in Lombardy (Italy): Comparison of receptor and chemistry-transport modelling results. Atmospheric Environment, 106, 56-70

Poluzzi, V., Trentini, A., Scotto, F., Ricciardelli, I., Ferrari, S., Maccone, C., Bacco, D., Zigola, C., Bonafè, G., Ugolini, P., Bertacci, G., Pietrogrande, M.C., Visentin, M., Gilardoni, S., Paglione, M., Rinaldi, M., Facchini, M.C. (2015). Preliminary results of the project "Supersito" concerning the atmospheric aerosol composition in Emilia-Romagna region, Italy: PM source apportionment and aerosol size distribution. In: Sustainable Development, WIT Transactions on The Built Environment, 168, 689-698, DOI. 10.2495/SD150602.

Putaud, J., Van Dingenen, R., Alastuey, A., Bauer, H., Birmili, W., Cyrys, J., Flentje, H., Fuzzi, S., Gehrig, R., Hansson, H., Harrison, R., Herrmann, H., Hitzenberger, R., Huglin, C., Jones, A., Kasper-Giebl, A., Kiss, G., Kousa, A., Kuhlbusch, T., Loschau, G., Maenhaut, W., Molnar, A., Moreno, T., Pekkanen, J., Perrino, C., Pitz, M., Puxbaum, H., Querol, X., Rodriguez, S., Salma, I., Schwarz, J., Smolik, J., Schneider, 
J., Spindler, G., ten Brink, H., Tursic, J., Viana, M., Wiedensohler, A., Raes, F., (2010). A European aerosol phenomenology-3: Physical and chemical characteristics of particulate matter from 60 rural, urban, and kerbside sites across Europe, Atmospheric Environment, 44, 1308-1320, doi:10.1016/j.atmosenv.2009.12.011, 2010.

Rao, S.T., Sistla, G., Pagnotti, V., Petersen, B.W., Irwin, S.J. Turner, B.D. (1985) Evaluation of the Performance of RAM With The Regional Air Pollution Study Data Base, Atmospheric Environment, 19, 229-245.

Ricciardelli, I., Bacco, D., Rinaldi, M., Bonafè, G., Scotto, F., Trentini, A., Bertacci, G., Ugolini, P., Zigola, C., Rovere, F., Maccone, C., Pironi, C., Poluzzi, V. (2017). V. A three-year investigation of daily PM2.5 main chemical components in four sites: the routine measurement program of the Supersito Project (Po Valley, Italy), Atmospheric Environment, 152, 418-430, http://dx.doi.org/10.1016/j.atmosenv.2016.12.052.

Robinson, A.L., Donahue, N.M., Shrivastava, M.K., Weitkamp, E.A., Sage, A.M., Grieshop, A.P., Lane, T.E., Pierce, J.R., Pandis, S.N. (2007). Rethinking organic aerosols: Semivolatile emissions and photochemical aging, Science, 315(5816), 1259-1262.

Shorshani, M.F., Shekarrizfard, M., Hatzopoulou, M. (2017). Evaluation of regional and local atmospheric dispersion models for the analysis of traffic-related air pollution in urban areas, Atmospheric Environment, 167, 270-282. https://doi.org/10.1016/j.atmosenv.2017.08.025.

Skamarock, W.C., Klemp, J.B., Dudhia, J., Gill, D.O., Barker, D.M., Duda, M.G., Huang, X.Y., Wang, W., Powers, J.G., (2008). A Description of the Advanced Research WRF Version 3. NCAR Technical Note NCAR/TN-475pSTR, Boulder, Colorado.

Strader, R., Lurmann, F., Pandis, S.N. (1999). Evaluation of secondary organic aerosol formation in winter, Atmospheric Environment, 33, 4849-4863.

Tsimpidi, A.P. (2010). Evaluation of the volatility basis-set approach for the simulation of organic aerosol formation in the Mexico city metropolitan area, Atmospheric Chemistry and Physics, 10, 525-546.

UNC (2013). SMOKE v3.5 User's manual. Available at: http://www.smoke-model.org/index.cfm.

WHO (2016). European Detailed Mortality Database, update July 2016, Copenhagen, WHO Regional Office for Europe (http://data.euro.who.int/dmdb/).

Yarwood, G., Rao, S., Yocke, M., Whitten, G. (2005). Updates to the Carbon Bond Chemical mechanism: CB05, report, Rpt. RT-0400675, US EPA, Res. Tri. Park.

Zhang, M., Uno, I., Zhang, R., Han, Z., Wang, Z., Pu, Y. (2006a). Evaluation of the Models-3 Community Multi-scale Air Quality (CMAQ) modeling system with observations obtained during the TRACE-P experiment: Comparison of ozone and its related species, Atmospheric Environment, 40, 4874-4882. https://doi.org/10.1016/j.atmosenv.2005.06.063.

Zhang, Y., Liu, P, Pun, B., Seigneur, C. (2006b). A comprehensive performance evaluation of MM5-CMAQ for the summer 1999 southern oxidants study episode, Part III: Diagnostic and mechanistic evaluations, Atmospheric Environment, 40, 4856-4873. https://doi.org/10.1016/j.atmosenv.2005.12.046.

Zhang, Q., Jimenez, J., Canagaratna, M., Allan, J., Coe, H., Ulbrich, I., Alfarra, M., Takami, A., Middlebrook, A., Sun, Y., Dzepina, K., Dunlea, E., Docherty, K., De Carlo, P., Salcedo, D., Onasch, T., Jayne, J., Miyoshi, T., Shimono, A., Hatakeyama,S., Takegawa, N., Kondo, Y., Schneider, J., Drewnick, F., Borrmann, S., Weimer, S., Demerjian, K., Williams, P., Bower, K., Bahreini, R., Cottrell, L., Griffin, R., Rautiainen, J., Sun, J., Zhang, Y., Worsnop, D. (2007). Ubiquity and dominance of oxygenated species in organic aerosols in anthropogenically-influenced Northern Hemisphere midlatitudes, Geophysical Research Letters, 34(13).

Zhang, Q.J., Beekmann, M., Drewnick, F., Freutel, F., Schneider, J., Crippa, M., Prevot, A.S.H., Baltensperger, U., Poulain, L., Wiedensohler, A., Sciare, J., Gros, V., Borbon, A., Colomb, A., Michoud, V., Doussin, J.-F., Denier van der Gon, H.A.C., Haeffelin, M., Dupont, J.-C., Siour, G., Petetin, H., Bessagnet, B., Pandis, S.N., Hodzic, A., Sanchez, O., Honoré, C., Perrussel, O. (2013). Formation of 
organic aerosol in the Paris region during the MEGAPOLI summer campaign: Evaluation of the volatility-

Table 1. Availability of stations with hourly measurements for Meteorological ARPA dataset. Only sites with data

795 availability $>75 \%$ and height $<500$ ( $m$ a.s.l.) have been selected for Model Performance Evaluation.

\begin{tabular}{lccccc}
\hline & $\begin{array}{c}\text { Mixing } \\
\text { Ratio }\end{array}$ & Temperature & $\begin{array}{c}\text { Wind } \\
\text { speed }\end{array}$ & $\begin{array}{c}\text { Global } \\
\text { radiation }\end{array}$ & Rain \\
\hline Piemonte & 13 & 19 & 15 & 14 & 19 \\
Lombardia & 68 & 105 & 28 & 49 & 113 \\
Veneto & 27 & 27 & 26 & 27 & 26 \\
Emilia Romagna & 33 & 37 & 32 & 24 & 33 \\
\hline
\end{tabular}

Table 2. Availability of hourly measurements for Air Quality ARPA Dataset (daily for $\mathrm{PM}_{10}$ and $\mathrm{PM}_{2.5}$ ). Only sites with data availability $>75 \%$ and height $<700$ ( $\mathrm{m}$ a.s. $\mathrm{l}$ ) have been selected for Model Performance Evaluation.

\begin{tabular}{llccccc}
\hline & & $\mathbf{N O}_{\mathbf{x}}$ & $\mathbf{N O}_{\mathbf{2}}$ & $\mathbf{S O}_{\mathbf{2}}$ & $\mathbf{P M}_{\mathbf{1 0}}$ & $\mathbf{P M}_{\mathbf{2 . 5}}$ \\
\hline Whole Po Valley & RB & 31 & 36 & 6 & 16 & 6 \\
& SBUB & 130 & 136 & 34 & 74 & 28 \\
\multirow{4}{*}{ Liemonte } & RB & 8 & 12 & 4 & 4 & 3 \\
& SBUB & 30 & 31 & 10 & 17 & 9 \\
Veneto & RB & 7 & 8 & 1 & 3 & 3 \\
\multirow{3}{*}{ Emilia Romagna } & SBUB & 63 & 68 & 18 & 25 & 15 \\
& RB & 5 & 5 & 1 & 3 & - \\
& SBUB & 15 & 15 & 5 & 10 & 4 \\
& RB & 11 & 11 & - & 6 & - \\
\hline
\end{tabular}

Table 3 Statistical indices for model predicted concentrations of $\mathrm{PM}_{10}, \mathrm{PM}_{2.5}$.

\begin{tabular}{|c|c|c|c|c|c|c|c|c|c|}
\hline & & \multicolumn{4}{|c|}{$P M_{10}\left[\mu g m^{-3}\right]$} & \multicolumn{4}{|c|}{$P M_{2.5}\left[\mu g^{-3}{ }^{-3}\right]$} \\
\hline & & \multicolumn{2}{|c|}{$R B$} & \multicolumn{2}{|c|}{$\overline{S B U B}$} & \multicolumn{2}{|c|}{$\overline{R B}$} & \multicolumn{2}{|c|}{$\overline{S B U B}$} \\
\hline & & SOAP & $V B S$ & SOAP & $V B S$ & SOAP & $V B S$ & SOAP & $V B S$ \\
\hline $\begin{array}{l}\text { Number } \\
\text { observations }\end{array}$ & of & 439 & 439 & 2062 & 2062 & 161 & 161 & 793 & 793 \\
\hline Mean observed & & 31.95 & 31.95 & 39.26 & 39.26 & 30.43 & 30.43 & 34.98 & 34.98 \\
\hline Mean modelled & & 33.52 & 31.67 & 34.55 & 32.2 & 29.92 & 28.19 & 32.28 & 29.45 \\
\hline Bias & & 1.57 & -0.28 & -4.71 & -7.06 & -0.51 & -2.24 & -2.71 & -5.53 \\
\hline MAE & & 15.35 & 15.11 & 16.60 & 16.91 & 14.20 & 14.2 & 15.06 & 15.02 \\
\hline IOA & & 0.58 & 0.57 & 0.52 & 0.51 & 0.60 & 0.59 & 0.59 & 0.58 \\
\hline RMSE & & 20.07 & 20.22 & 22.63 & 23.3 & 19.14 & 19.37 & 19.80 & 20.06 \\
\hline
\end{tabular}

800

801

802

803

804

805 
Table 4. Statistical indices for model predicted concentrations of OA at Milano Pascal, Ispra and Bologna stations.

\begin{tabular}{|c|c|c|c|c|c|c|}
\hline & \multicolumn{6}{|c|}{$\overline{O A}\left[\mu \mathrm{g} \mathrm{m}^{-3}\right]$} \\
\hline & \multicolumn{2}{|c|}{ MILANO Pascal* } & \multicolumn{2}{|c|}{ ISPRA* } & \multicolumn{2}{|c|}{ BOLOGNA** } \\
\hline & SOAP & VBS & SOAP & VBS & SOAP & VBS \\
\hline $\begin{array}{l}\text { Number } \\
\text { observations }\end{array}$ & 28 & 28 & 28 & 28 & 491 & 491 \\
\hline Mean observed & 15.8 & 15.8 & 16.9 & 16.9 & 8.6 & 8.6 \\
\hline Mean modelled & 8.4 & 5.4 & 6.8 & 4.2 & 3.1 & 4.9 \\
\hline Bias & -7.4 & -10.4 & -10.1 & -12.6 & -3.3 & -5.5 \\
\hline MAE & 7.6 & 10.4 & 11.0 & 13.0 & 4.7 & 5.6 \\
\hline IOA & 0.53 & 0.48 & 0.54 & 0.49 & 0.54 & 0.52 \\
\hline
\end{tabular}

* Daily data; ** Hourly data

Table 5. Statistical indices for model predicted concentrations of OA at Bologna site. Observed data are derived from PMF factors, where: SOA = PMF factors OOA1+OOA2+OOA3 and CAMx species PASx+PBSx; DrySOA (i.e.: SOA from gas phase reactions) = $P M F$ factors OOA2+OOA3 and CAMx species PASx+PBSx; SOAB (i.e.: SOA only from biomass burning due to gas phase reactions) = PMF factor OOA2and CAMX species PBSX.

\begin{tabular}{|c|c|c|c|c|c|c|c|c|c|}
\hline \multirow{3}{*}{\multicolumn{2}{|c|}{$\mu \mathrm{g} \mathrm{m}^{-3}$}} & \multicolumn{6}{|c|}{ BOLOGNA } & \multirow{3}{*}{$\begin{array}{c}\text { DrSOA } \\
\text { VBS }\end{array}$} & \multirow{3}{*}{$\begin{array}{c}\text { SOAB } \\
\text { VBS }\end{array}$} \\
\hline & & \multicolumn{2}{|c|}{ POA } & \multirow{2}{*}{$\begin{array}{c}\text { HOA } \\
\text { VBS }\end{array}$} & \multirow{2}{*}{$\begin{array}{c}\text { BBOA } \\
\text { VBS }\end{array}$} & \multicolumn{2}{|c|}{ SOA } & & \\
\hline & & SOAP & VBS & & & SOAP & VBS & & \\
\hline $\begin{array}{l}\text { Number } \\
\text { observations }\end{array}$ & of & 491 & 491 & 491 & 491 & 491 & 491 & 491 & 491 \\
\hline Mean observed & & 3.6 & 3.6 & 1.1 & 2.5 & 4.5 & 4.5 & 3.0 & 1.1 \\
\hline Mean modelled & & 4.7 & 2.4 & 0.4 & 2.0 & 0.2 & 0.7 & 0.7 & 0.2 \\
\hline Bias & & 1.1 & -1.2 & -0.8 & -0.4 & -4.3 & -3.8 & -2.2 & -0.8 \\
\hline MAE & & 2.6 & 1.9 & 0.9 & 1.2 & 4.3 & 3.8 & 2.2 & 0.9 \\
\hline IOA & & 0.53 & 0.49 & 0.40 & 0.53 & 0.44 & 0.48 & 0.52 & 0.45 \\
\hline
\end{tabular}
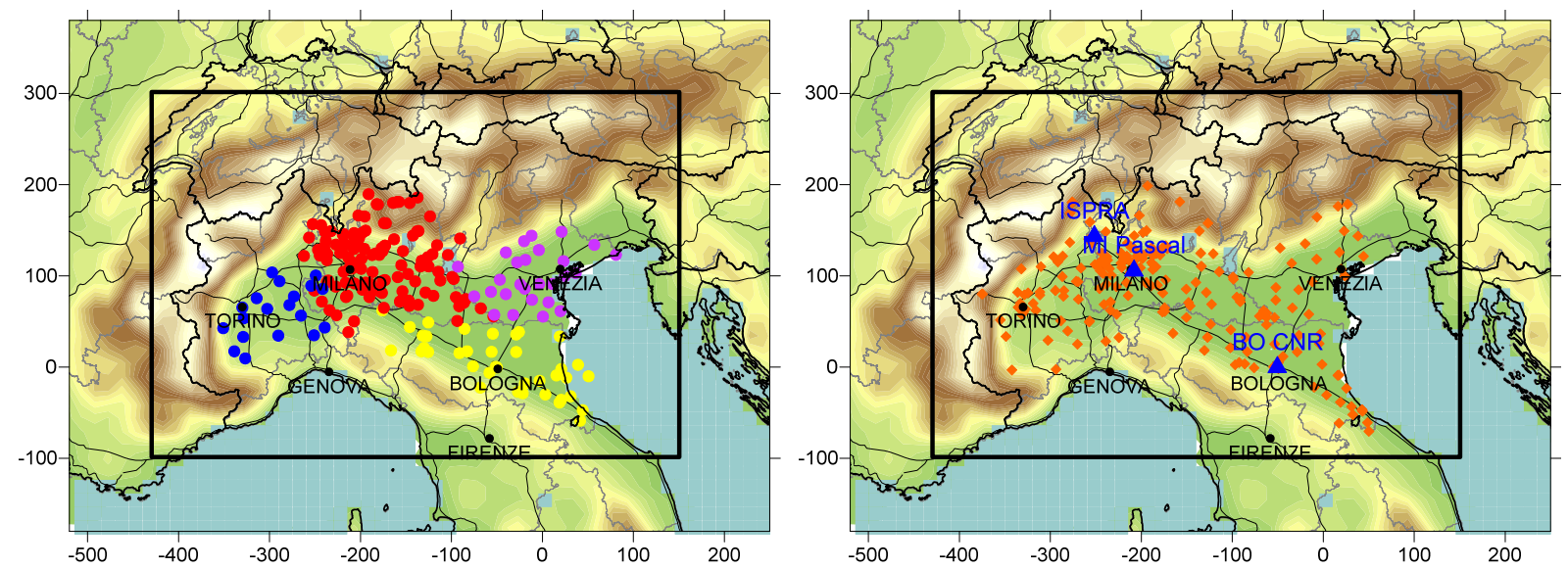

Figure 1. Meteorological and air quality datasets available over the Po Valley domain for the simulation period. In the left panel SMAM sites are in black, ARPA Piemonte sites in blue, ARPA Lombardia sites in red, ARPA Veneto sites in violet and ARPA Emilia Romagna sites in yellow. In the right panel AQ regional sites are in orange, while Ispra, Milano-Pascal and Bologna-CNR sites are in blue. Panels show also the main highways (dark blue). 

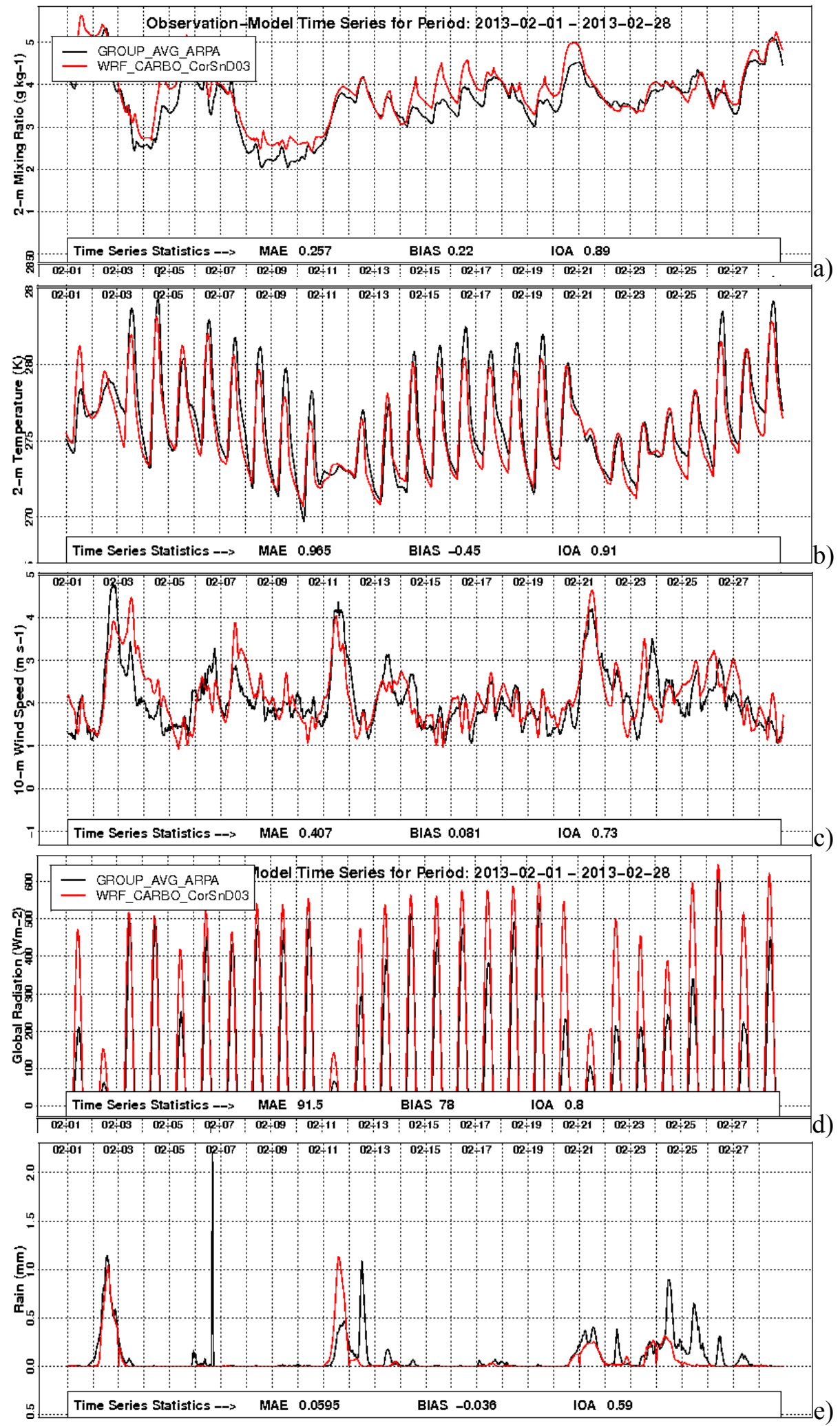
selected ARPA meteorological sites: a) water vapor mixing ratio; b) temperature; $c$ ) wind speed; d) global radiation; e) rain. 

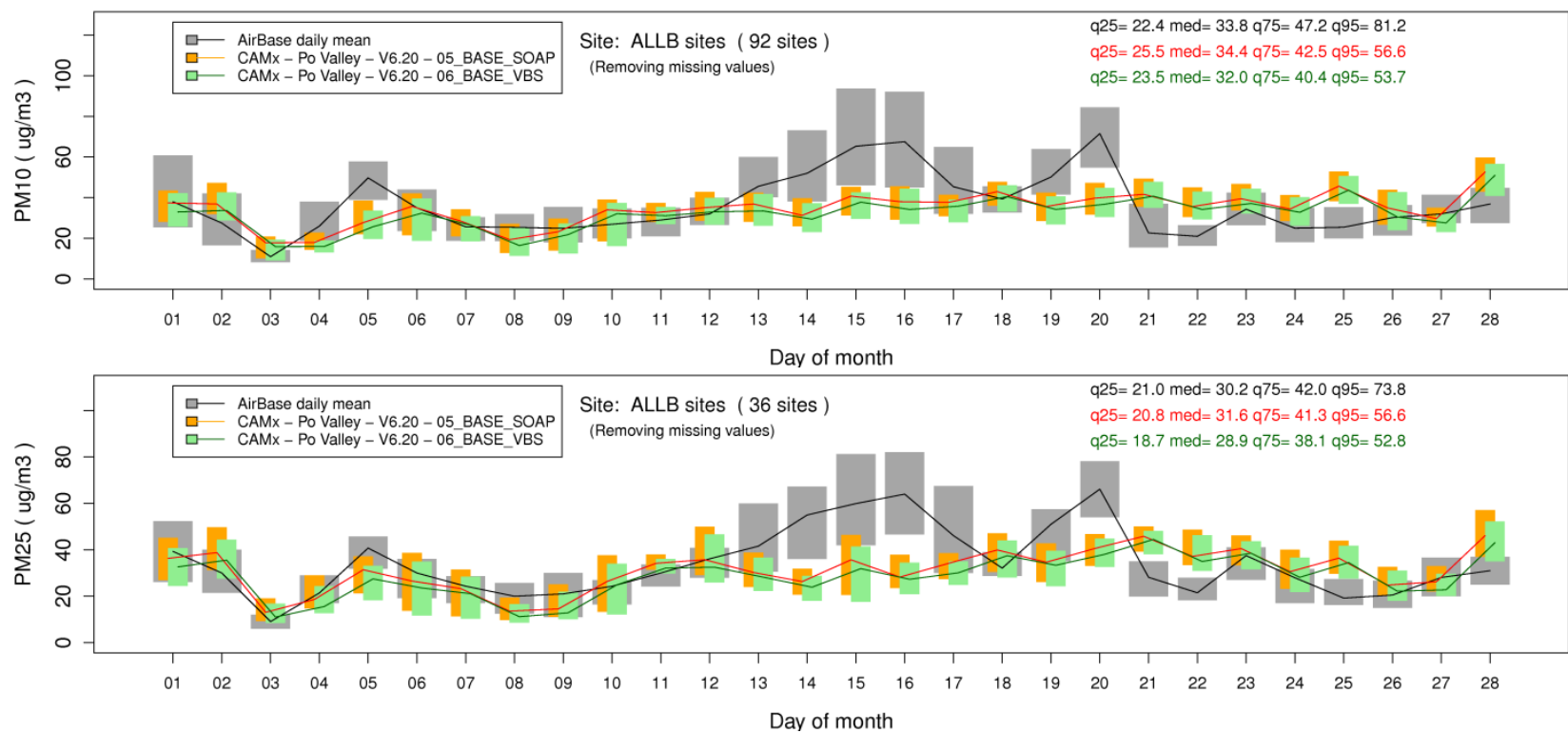

Figure 3. Time series of the box and whisker plots for the daily distribution of the observed (black/grey) and computed ("SOAP" red/orange; "VBS" light/dark green) values of $\mathrm{PM}_{10}$ and $\mathrm{PM}_{2.5}$ concentration $\left(\mu \mathrm{g} / \mathrm{m}^{3}\right.$ ) at background monitoring sites of the AQ regional networks for February 1-28. Bars show the interquartile range, lines the median values. Values for the 25th, 50th, 75th, and 95th quantiles of the whole monthly time series are reported too.
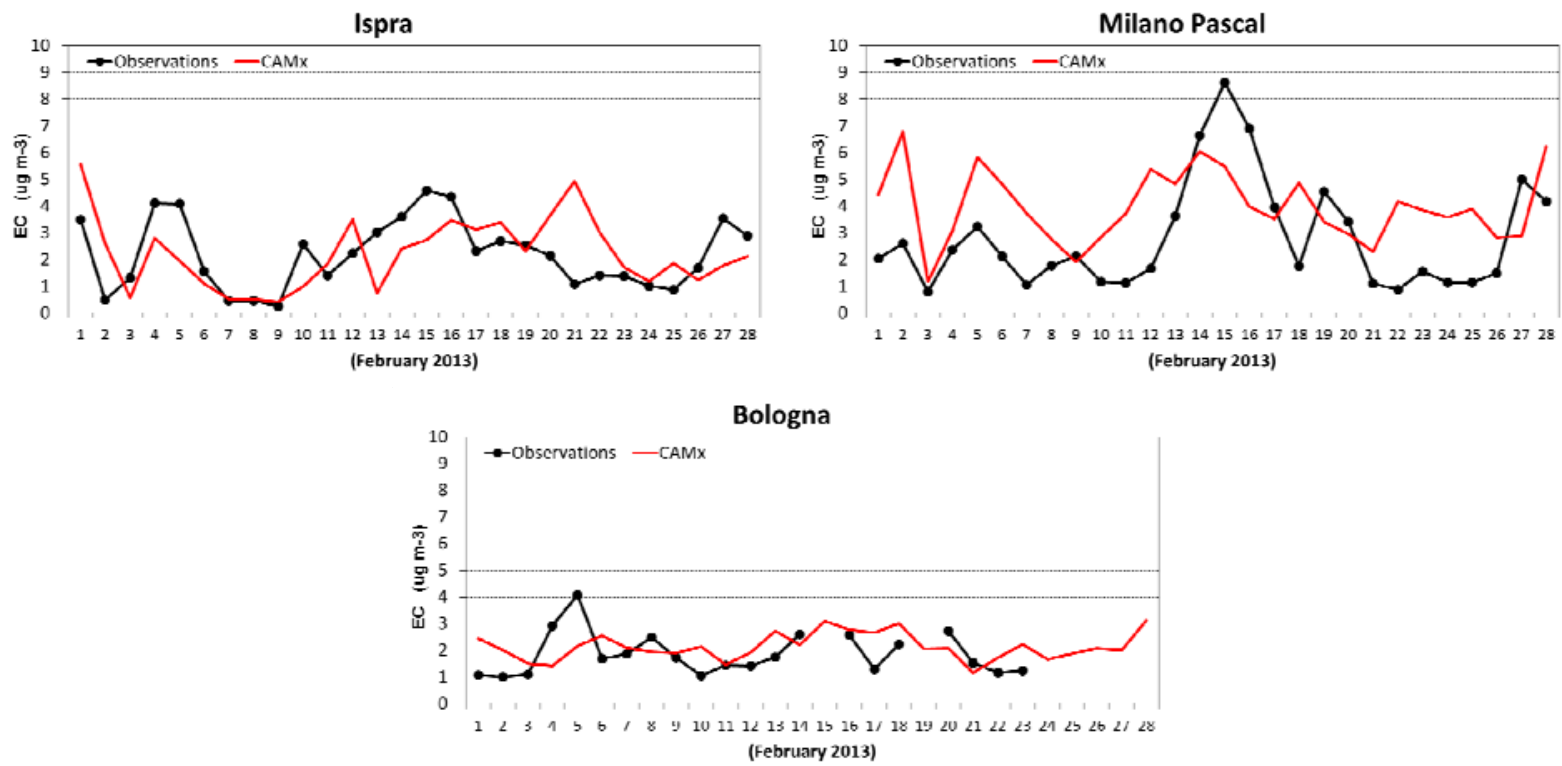

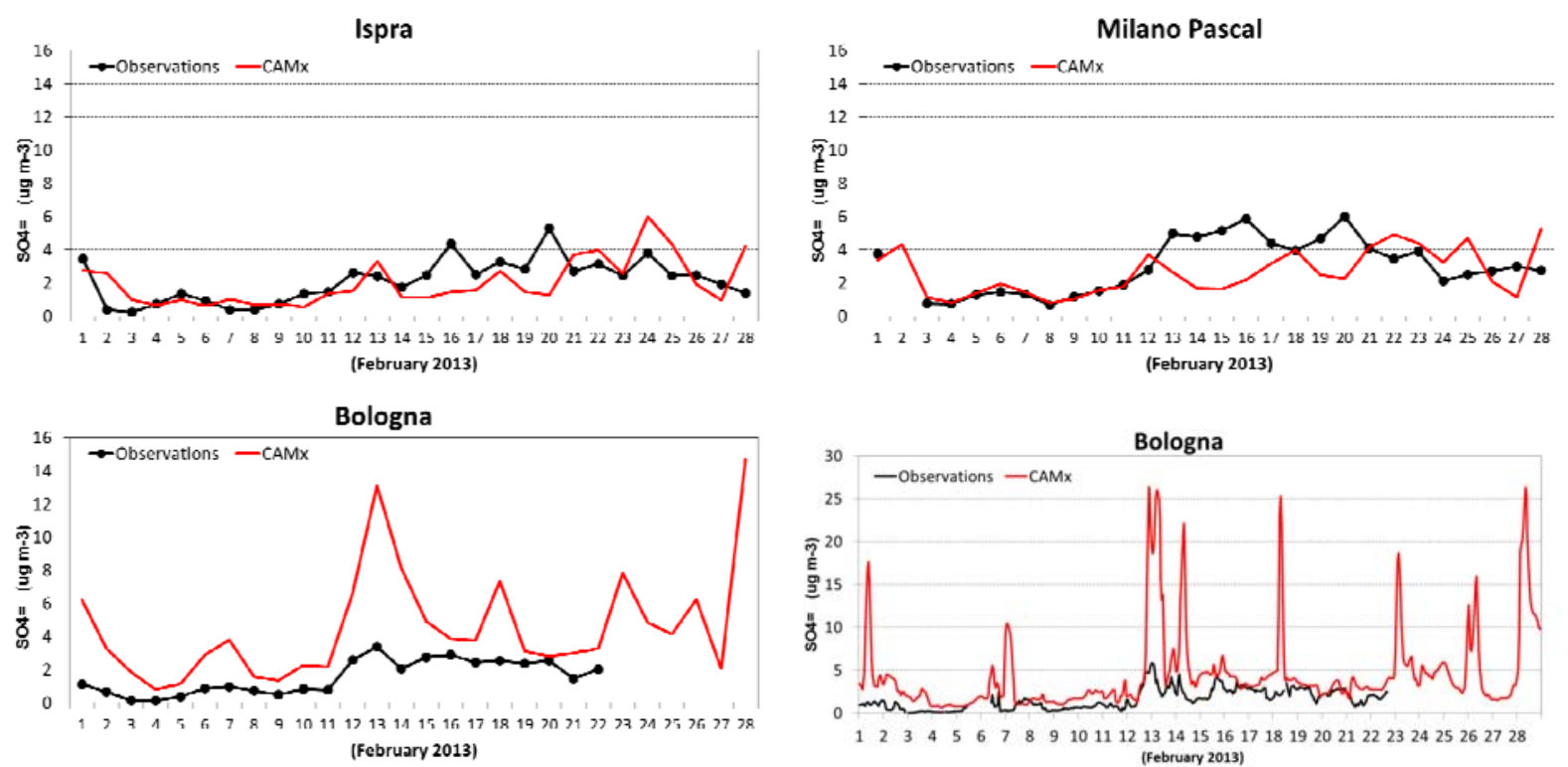
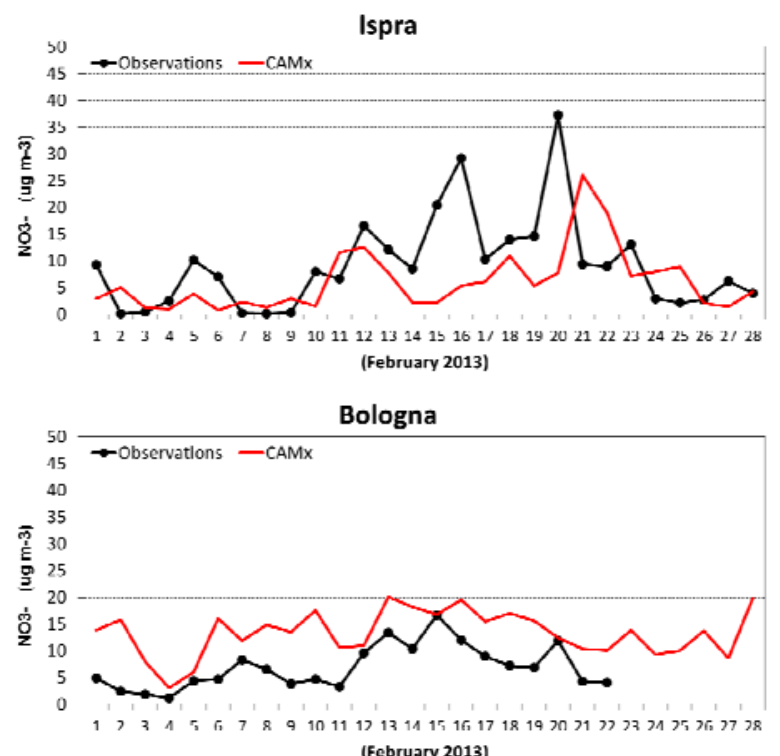
Ispra (daily) and Bologna (daily and hourly) stations. Ispra (daily) and Bologna (daily and hourly) stations.

Figure 5. Comparison of model predictions (red) with daily measurements (black) of sulfate at Milano Pascal (daily),
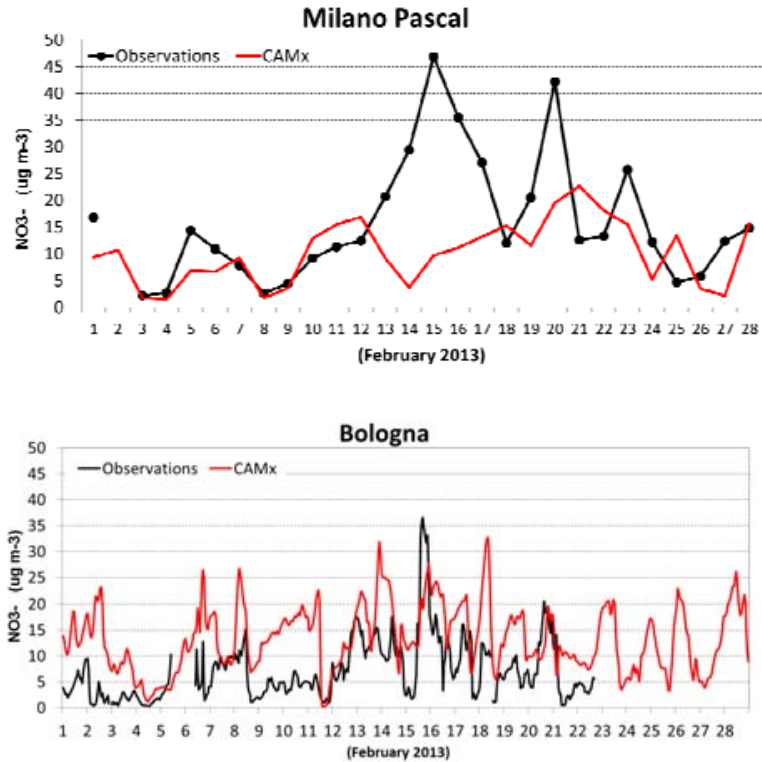

Figure 6. Comparison of model predictions (red) with daily measurements (black) of nitrate at Milano Pascal (daily), 

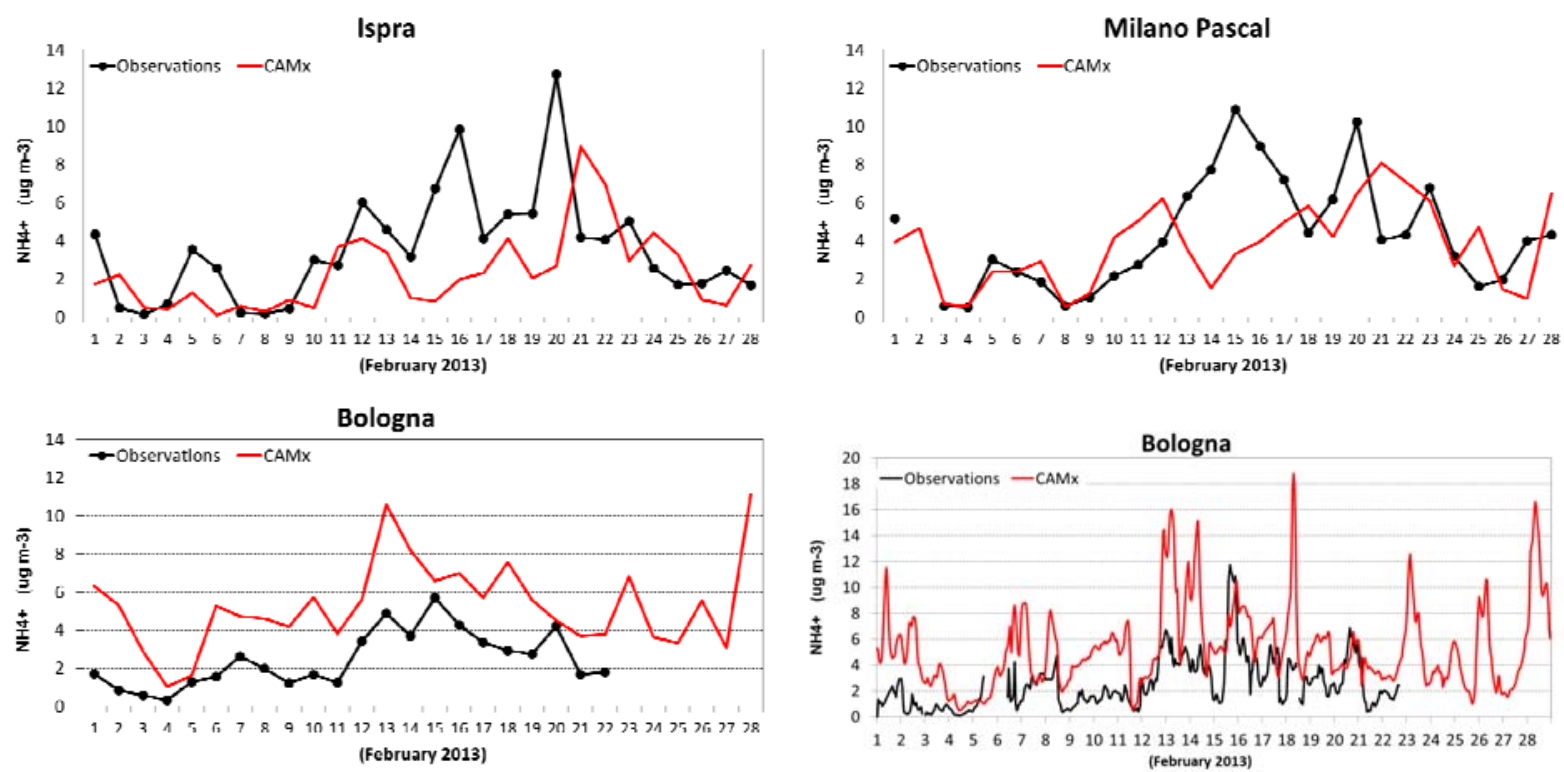
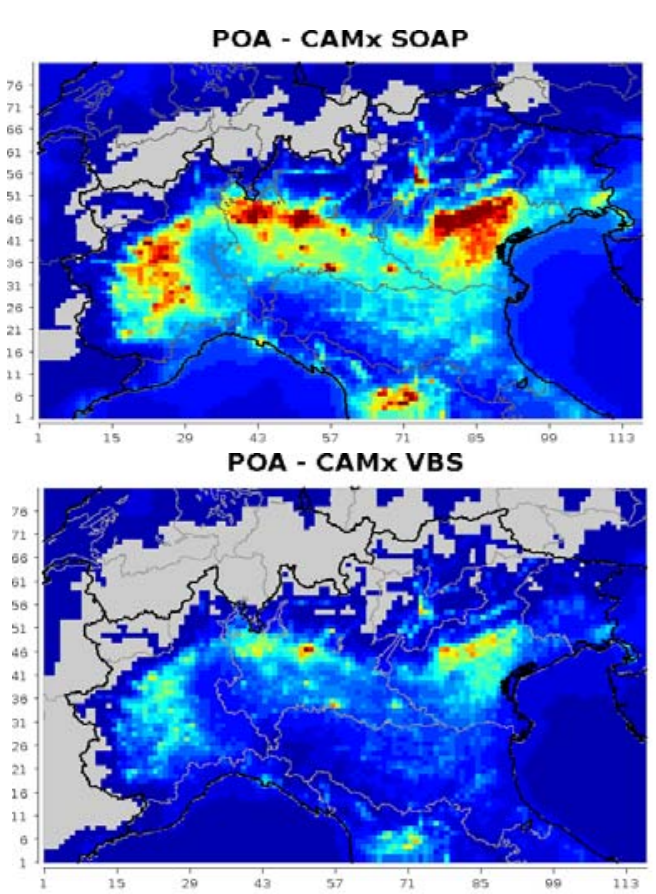

Figure 7. Comparison of model predictions (red) with daily measurements (black) of ammonium at Milano Pascal (daily), Ispra (daily) and Bologna (daily and hourly) stations.
Figure 8. Modeled ground-level concentrations of POA (left) and SOA (right) computed by CAMx - SOAP (top) and CAMx - VBS (bottom), averaged over the entire simulation period (1-28 February 2013). 

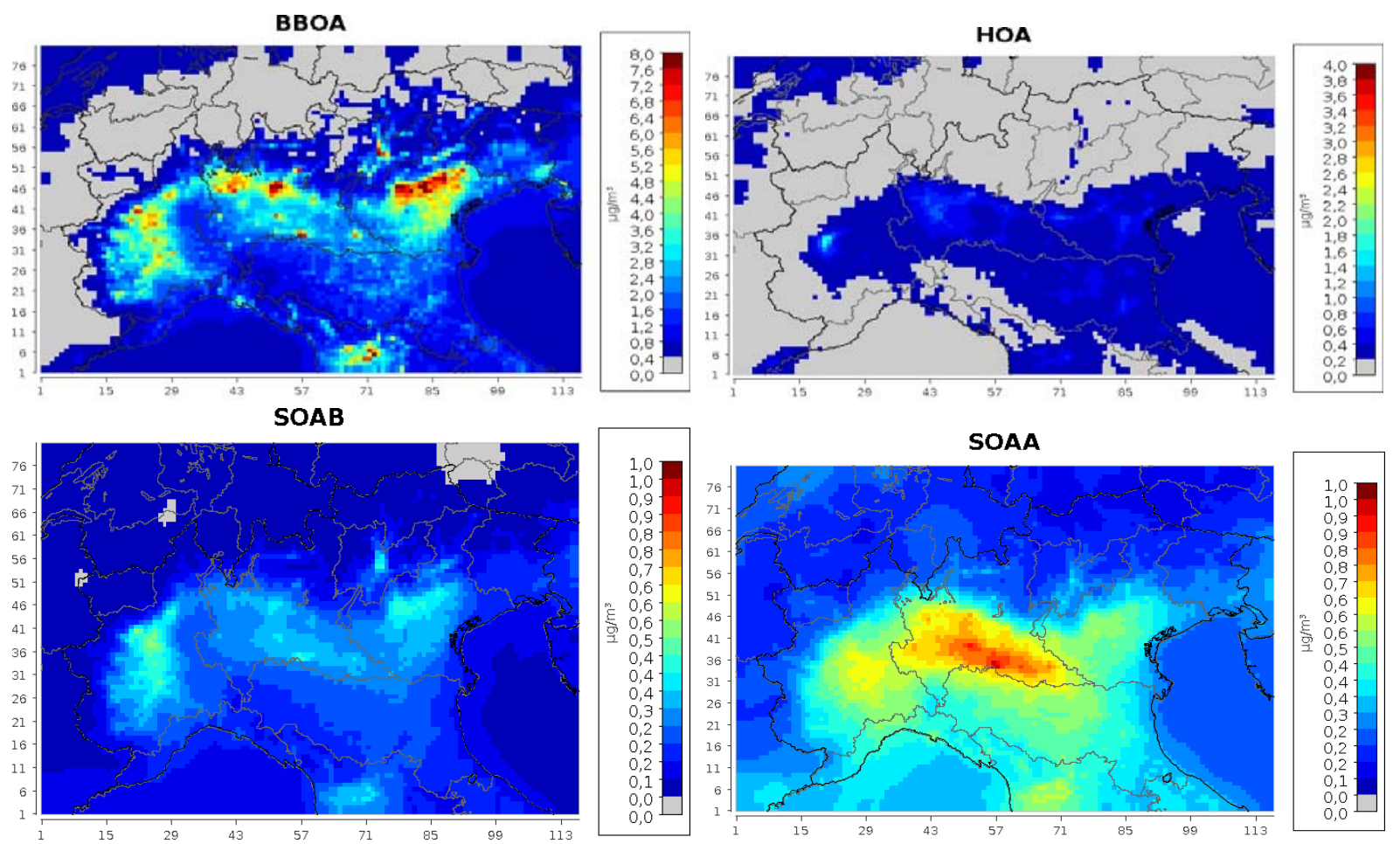

Figure 9. Modeled ground-level concentrations of POA (top) and SOA (bottom) computed by CAMx - VBS, averaged over the entire simulation period (1-28 February 2013). Left panels refer to OA produced by biomass burning and biogenic processes (BBOA and SOAB), right panels to OA produced from fossil fuel combustion (HOA and SOAA).
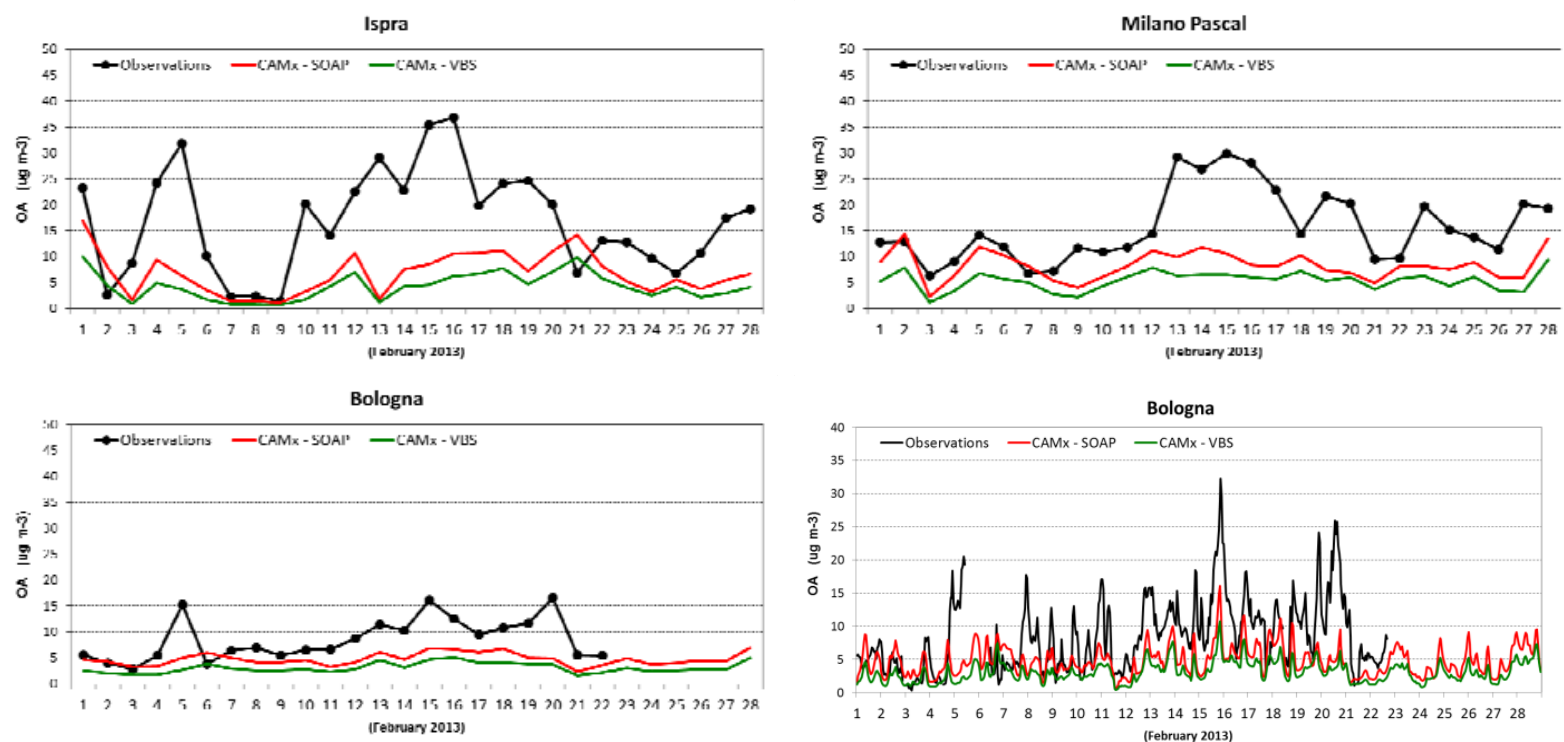

Figure 10. Comparison of model predictions (red for CAMx SOAP, green for CAMx VBS) with daily measurements (black) of Total Organic Aerosol at Milano Pascal (daily), Ispra (daily) and Bologna (daily and hourly) site. 


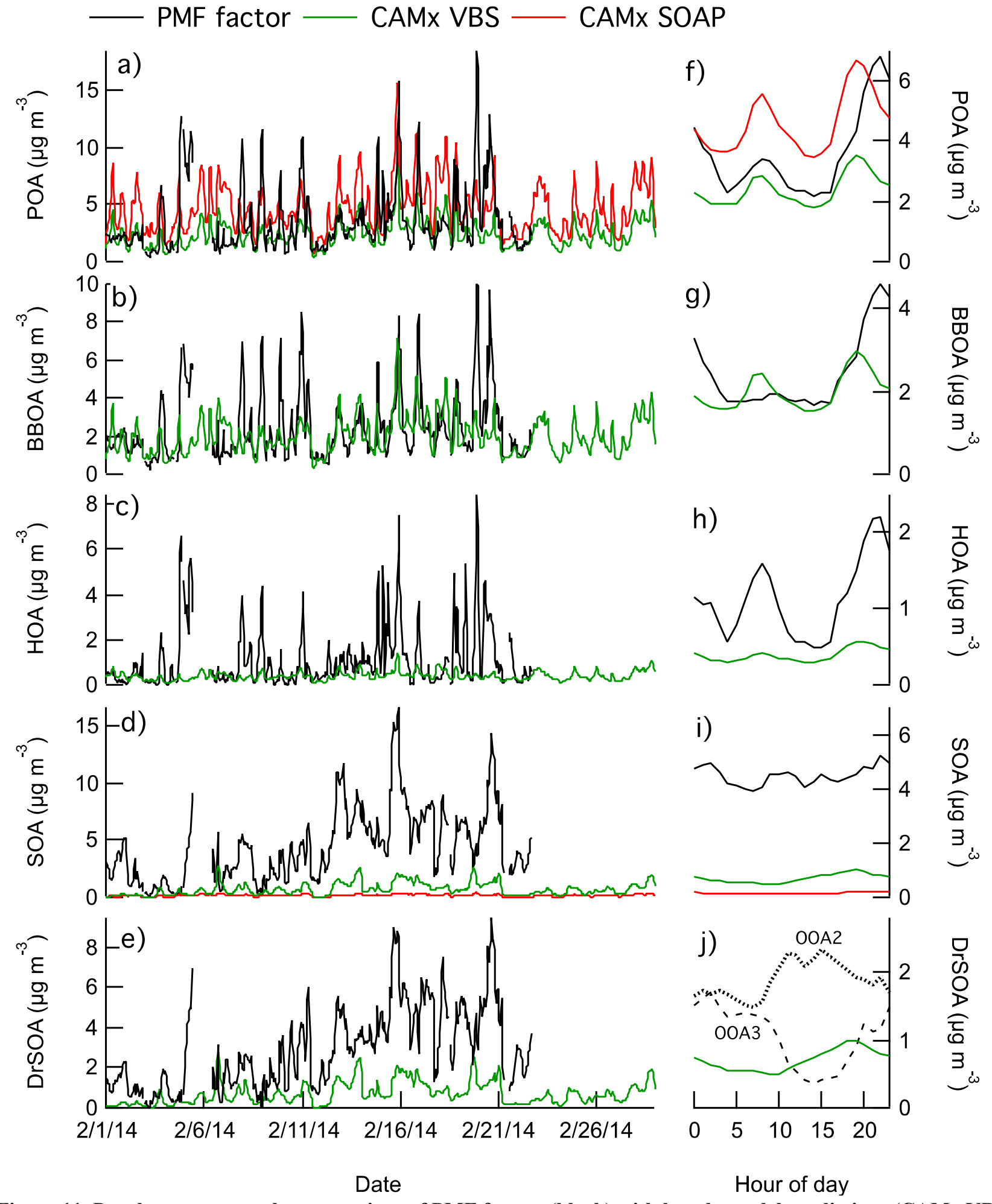

Figure 11. Panels a - e report the comparison of PMF factors (black) with hourly model predictions (CAMx VBS in green and CAMx SOAP in red): a) total POA, b) POA from biomass burning (BBOA), c) POA from hydrocarbon like OA (HOA), d) total SOA (PMF factors OOA1+OOA2+OOA3 and CAMx species PASx+PBSx), e) SOA from gas phase reactions (PMF factors OOA2+OOA3 and CAMx species PASx+PBSx). Panels f-j compare the modelled mean day with PMF factor diurnal profiles. 